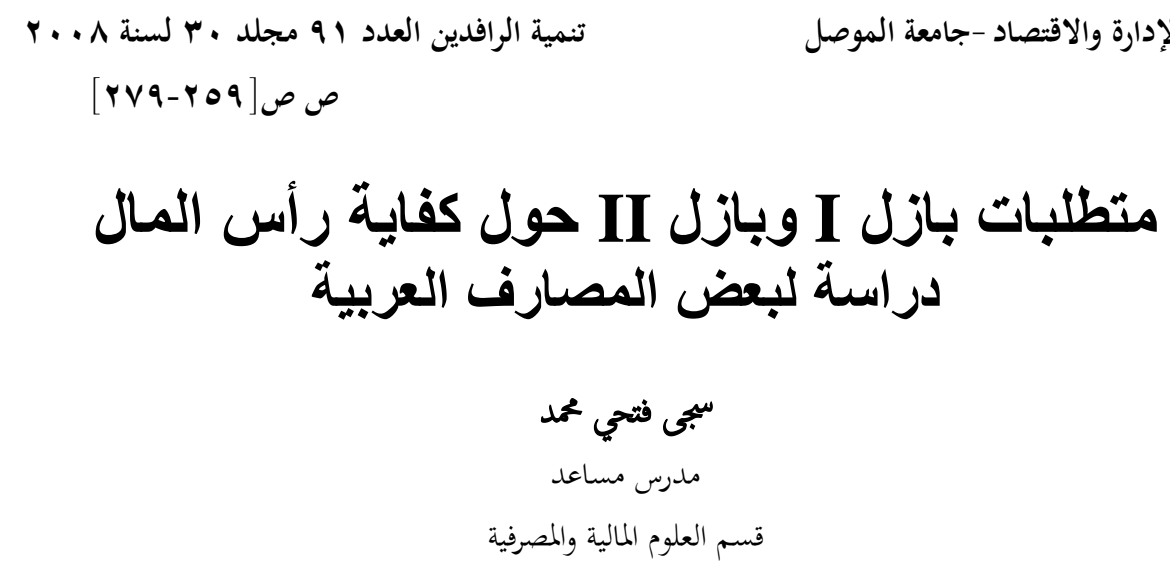

Saja_fathe@yahoo.com

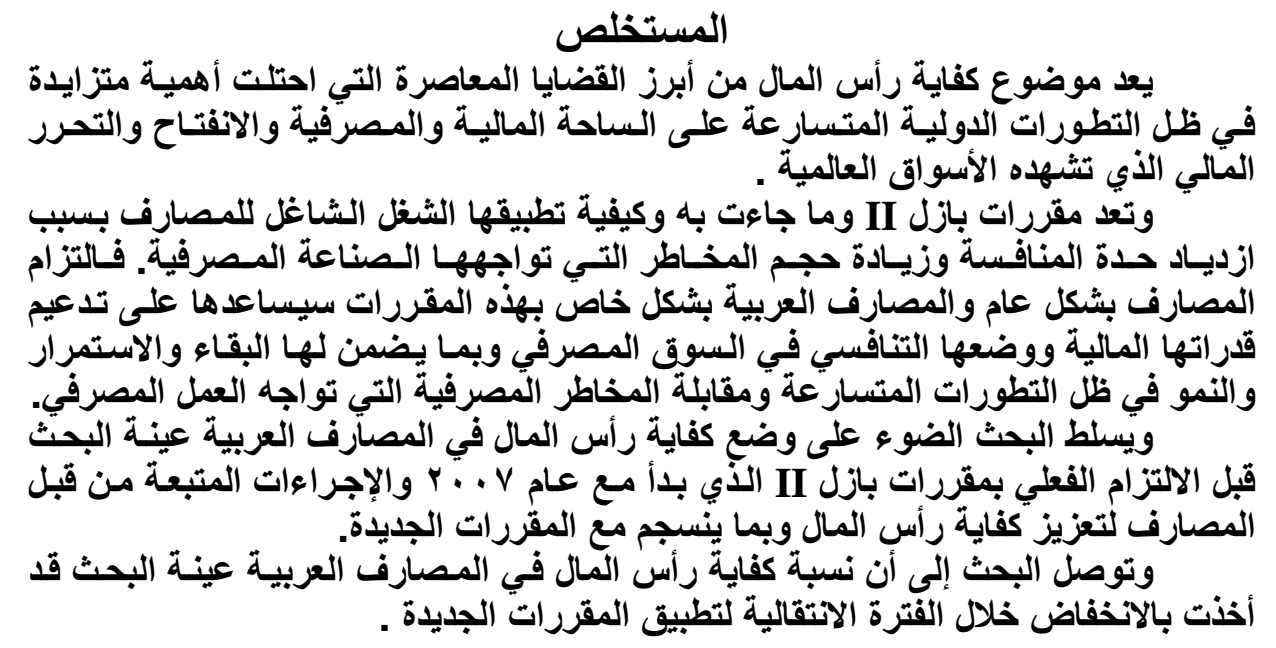

\title{
Standards Basle I and Basle II about Capital Adequacy: A Study of Some Arabic Banks
}

Saja F. Mohammed

Department of Financial and banking Sciences

University of Mosul

\section{ABSTRACT}

The capital adequacy considers one of the most contemporary issues. It occupied the increasing importance and took the consideration in the light of universal development in the financial and banking field with the financial liberalization in the universal financial markets. Basle II rules and how to apply it, is the important function of the banks, because of increased competition and risk facing the banking industry. The commitments of banks in general and Arabic banks with these rules will help it to support the financial ability and the competition in the

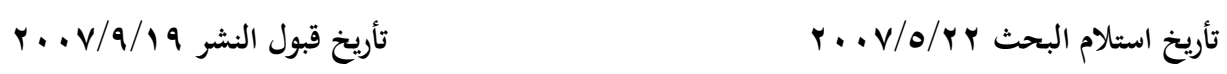


banking markets to ensure the existence, continuation and the growth in the light of continues development which facing the bank risk in the banking work. The present research deals with the capital adequacy in the Arabic banks as a sample before realistic committed with Basel II rules which started at 2007 and the procedures adopted by banks to support the capital adequacy which deals with new rules. The research concludes that the rate of capital adequacy in Arabic banks as a sample was reduced through out the shifting period in applying the new rules.

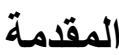

يعد موضو ع كفاية رأس المال من اهم المو اضيع التي حازت على الهى اهتمـام

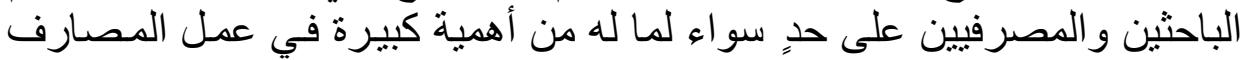

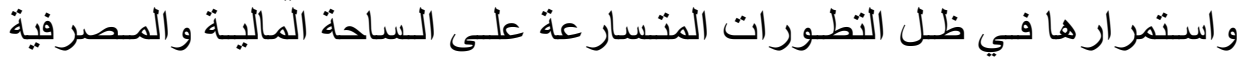

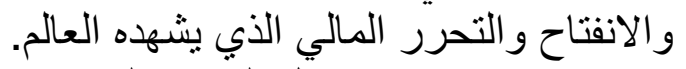

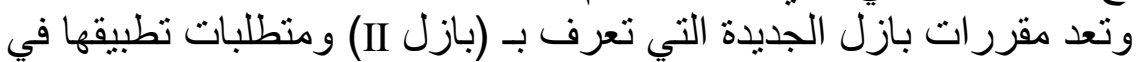

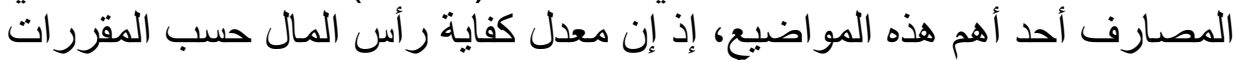

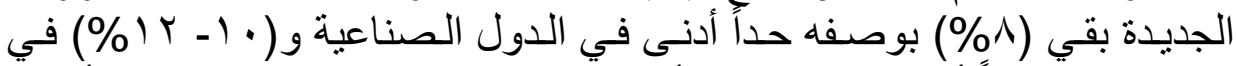

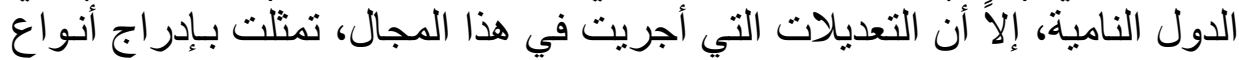

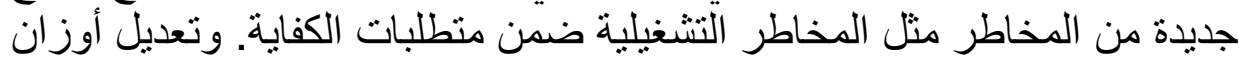

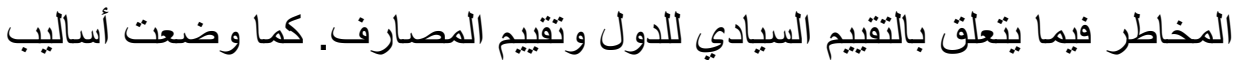

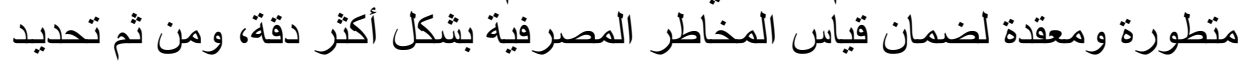
رأس المال الكافي لتغطية أية خسائر غير منوقعة وبما ينسجم مـع المعدل المحدد المدي ضمن هذه المقررات.

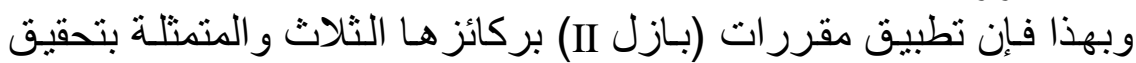

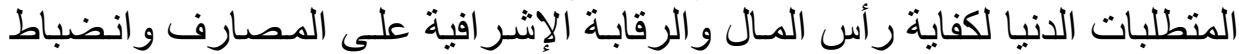

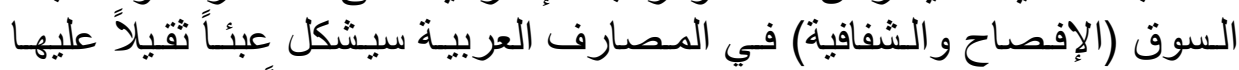

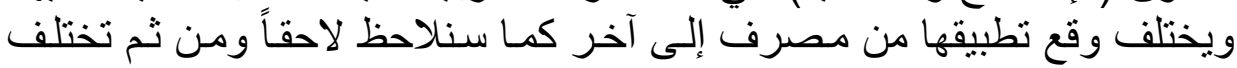

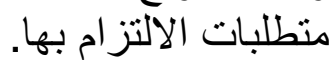

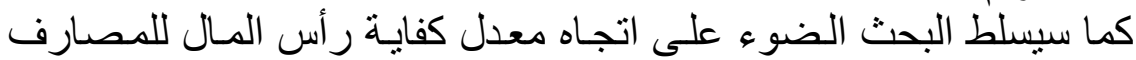

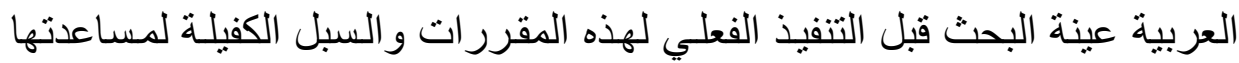

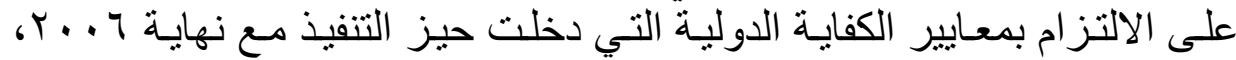

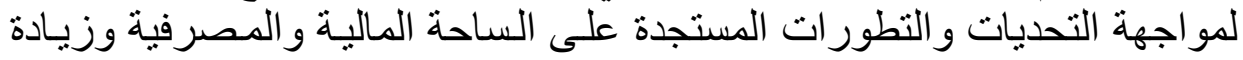

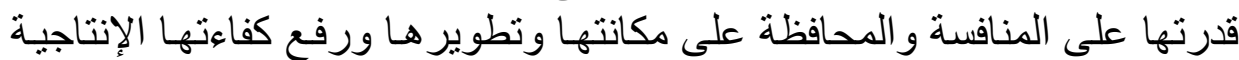

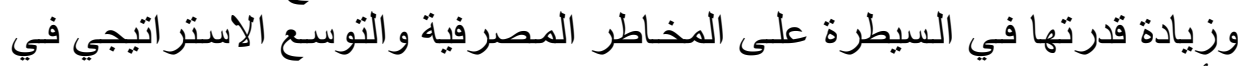
الأسو اق العالمية.

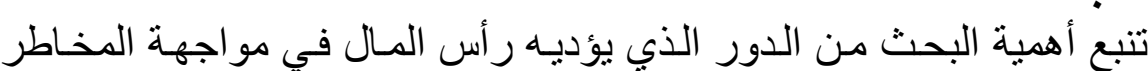

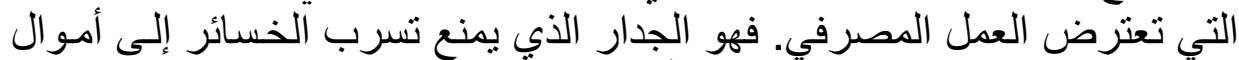

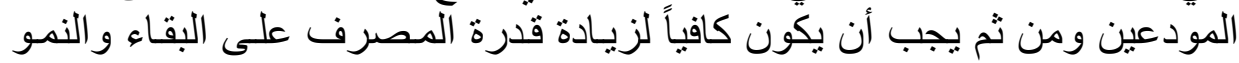




\section{محمد [rT!}

في ظل المنافسة الحادة التي تشهدها الدصارف اليوم. فكفاية رأس المـال في ظل إلـل

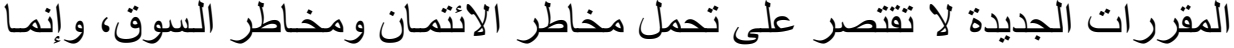

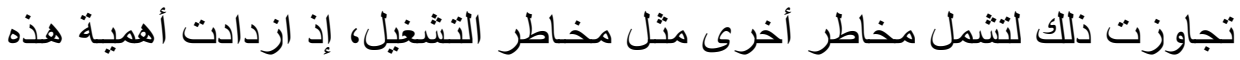

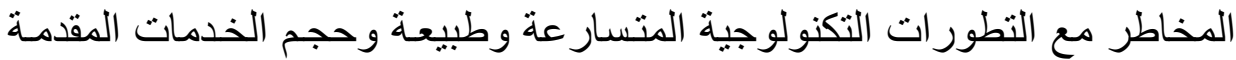

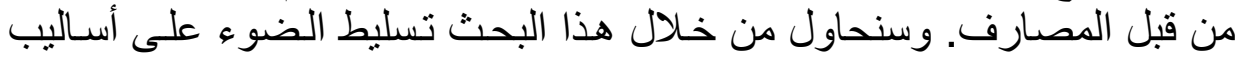

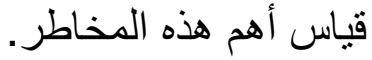

مشكلة البحث

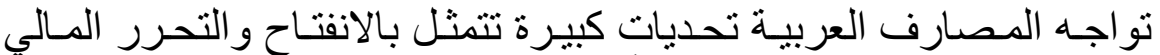

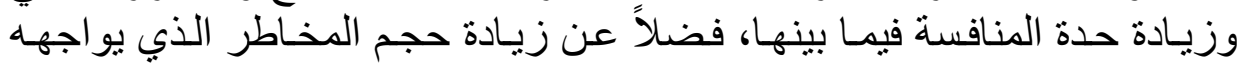

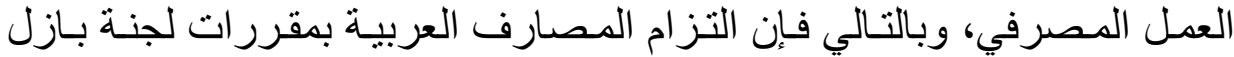

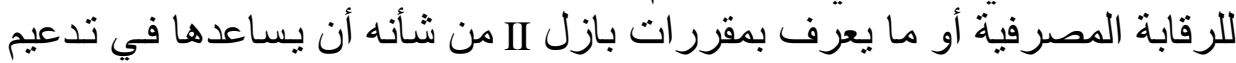

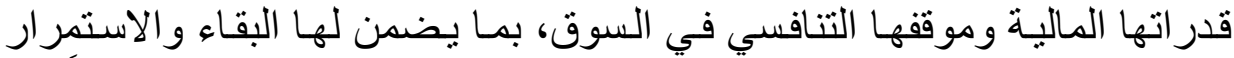

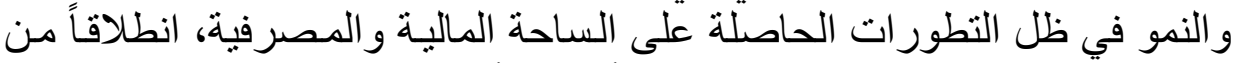
ذلك سيتركز عرض مشكلة البحث في الأسئلة آلآتية:

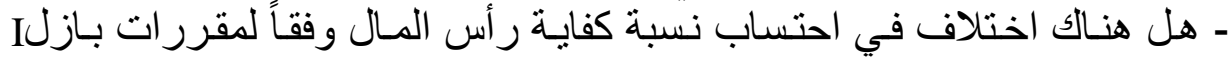

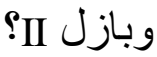
- هل بامكان المصارف العربية أن تلتزم بمـا جاءت بـه مقررات لجنـة بـازل

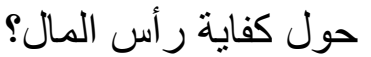
- ماهي المقومات و المنطلبات اللازمة لتطبيق المقررات الجديدة (بـازل II )، ومـا هي ألمعوقات التي تقف أمام تطبيقها؟

$$
\text { هدف البحث البحث إلى تحقيق الآتي: }
$$

\section{هدف البحث}

ا ـ بيان أوجه الاختلاف في احتساب نسبة كفاية رأس المال وفقا لمقرر ات بازل

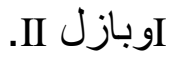

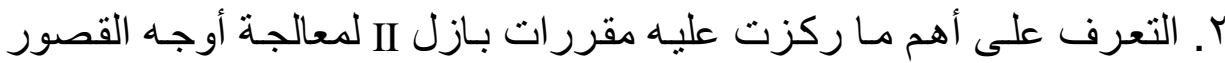

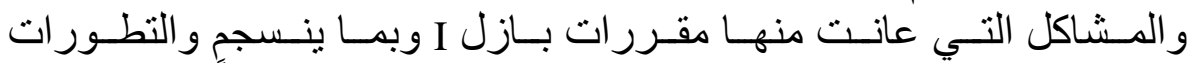

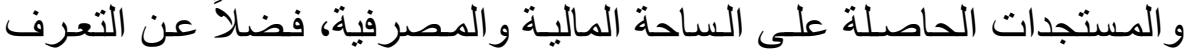

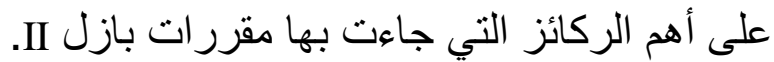

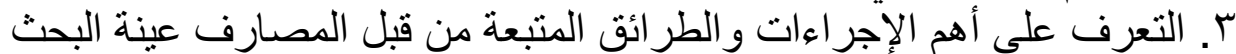
لتعزيز القدرة المالية بما ينسجم مع المقررات الفئ الجديدة. يتبنى البحث فرضيتين رئيستين مفادهما: فرضية البحث

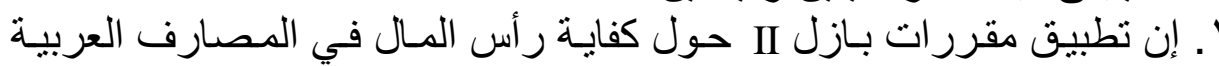

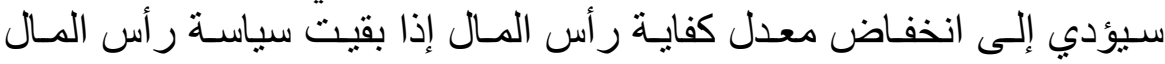

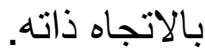


Y. سيكون من الصعب على المصارف العربية الالتز ام بنسبة بـازل II إذا بقيت سياسة رأس المال بوضعها الحالي.

عينة البحث وحدودها

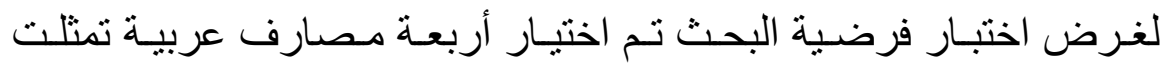

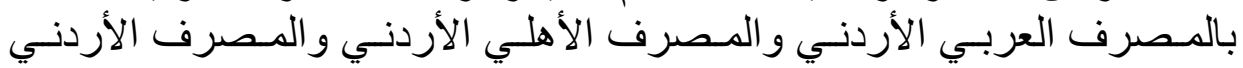

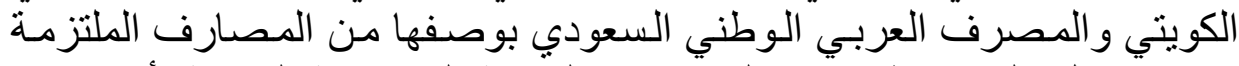

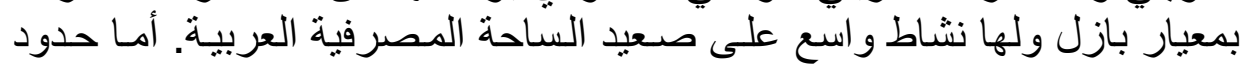

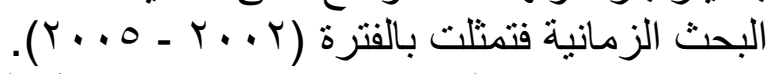

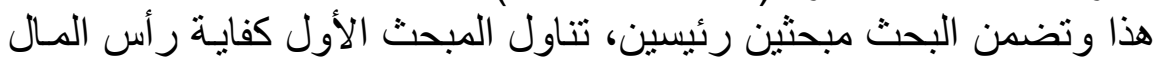

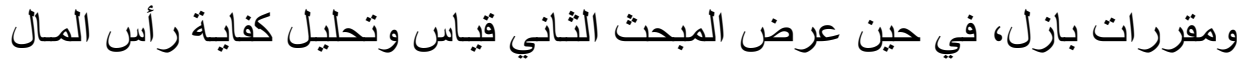

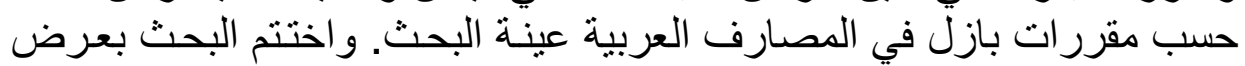
خلاصة لأبرز النتائج التي توصل إليهار الئا

$$
\text { كفاية رأس المال ومقررات بازل }
$$

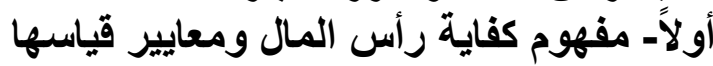

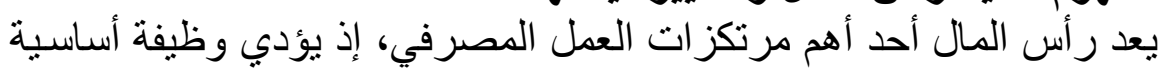

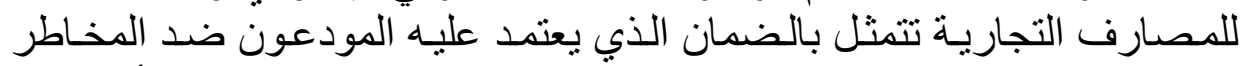

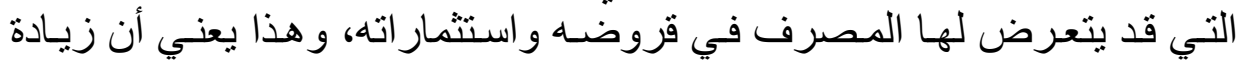

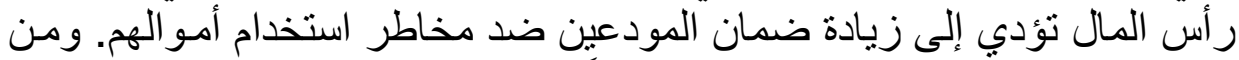

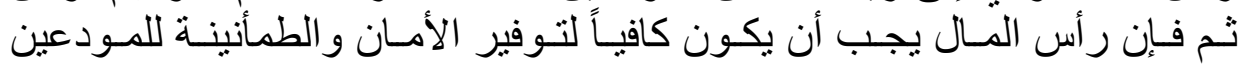

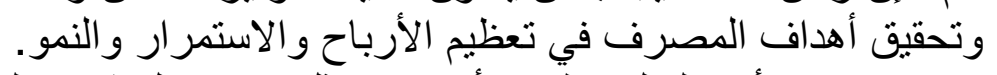

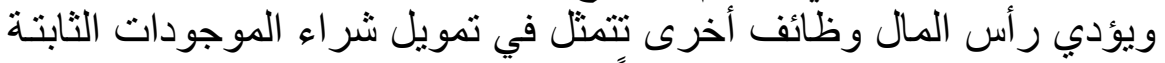

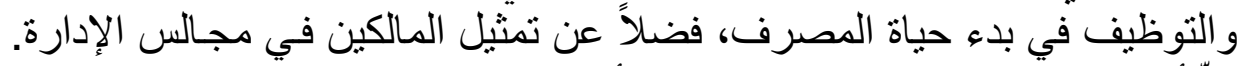

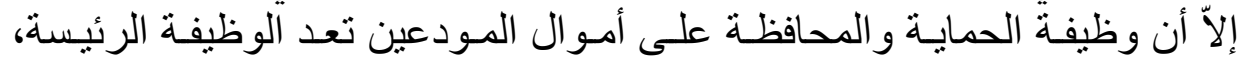

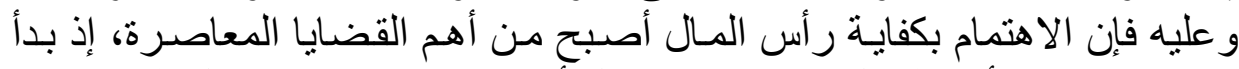

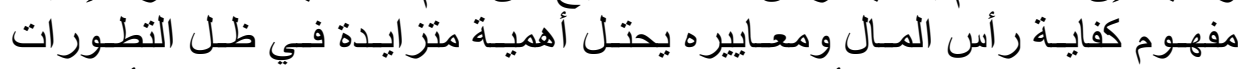

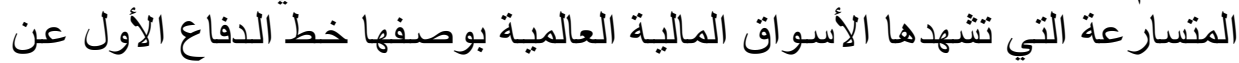

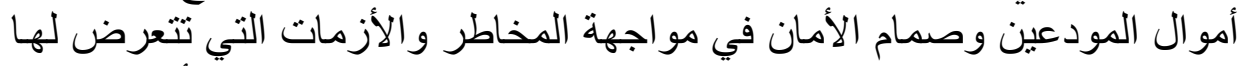

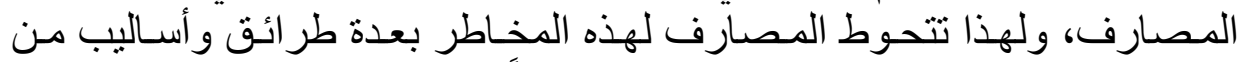

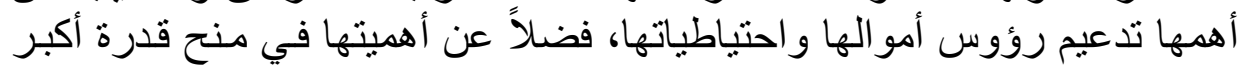

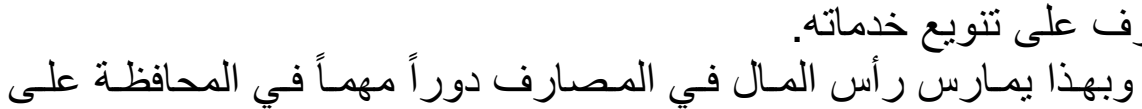

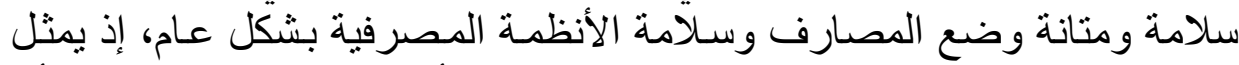

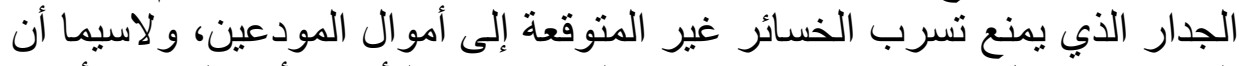
المصارف تعمل في بيئة تكتنفها درجة عالية من عدم التأكد، الأمر الذي ينثاً عنده 


\section{محمد [rqr}

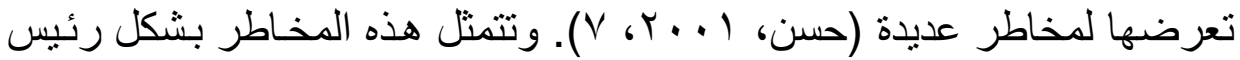

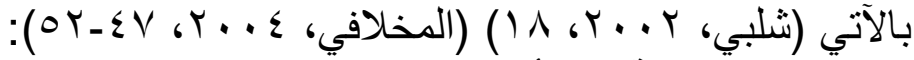

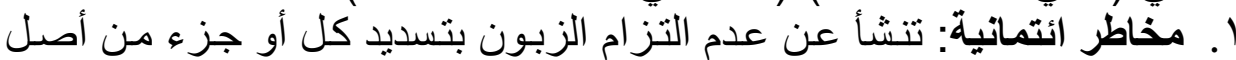

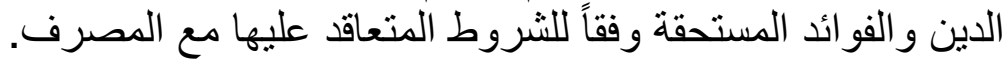

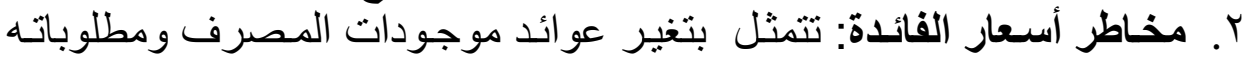
وقيمها بسبب تقلب أسعار الفائدة.

r. مخـاطر السيولة: تنشأ عن عدم قدرة المصرف على سـداد التزاماتـه عند استحقاقها.

؛. مخاطر السوق: تشمل المخاطر التي تتعرض لها الأرباح أو رأس المال نتيجة

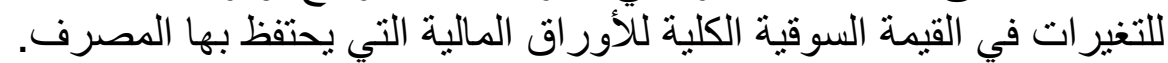

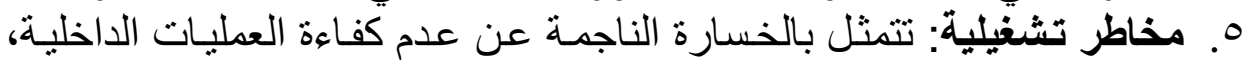
و والأفر اد و النظم أو فثلئها. 7. مخاطر إستراتيجية: وتشير إلى مدى قدرة المصرف على اليى اختيار المناطق

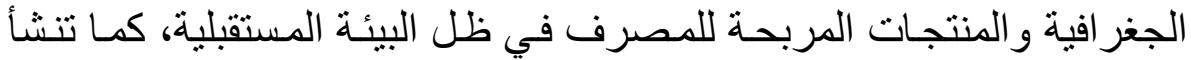
عن تقييم الإدارة الخاطئ لبيئة الأعمال التي تبنى لقئى على أساسها الإستر اتيجية.

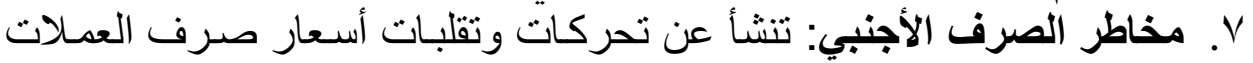
الأجنبية مقابل العملة الدحلية. ^. مخـاطر الالتزام: تنشـأ عن الإخـلال أو عدم الالتنز ام بـالقو انين و التشريعات السائدة. 9. مخاطر السمعة: تنشأ عن تكوّن صورة سيئة عن المصرف لـونة لدى الر أي العام،

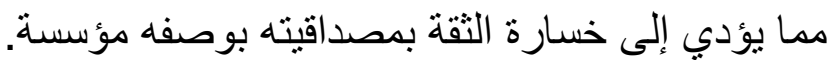

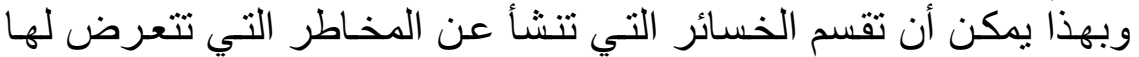

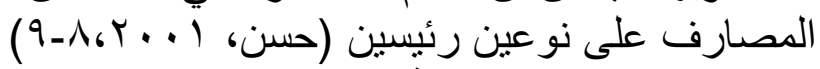

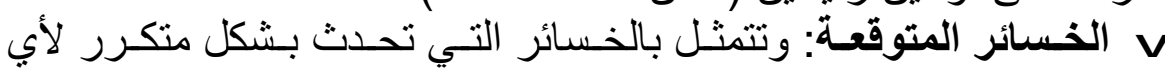

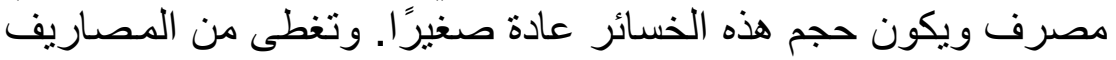

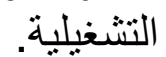
الخسائر غير المتوقعة: وتشمل الخسائر التي تحدث نـادراً، إلاّ أن آثارهـا

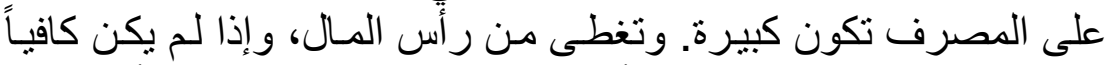

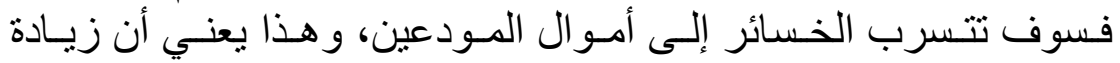

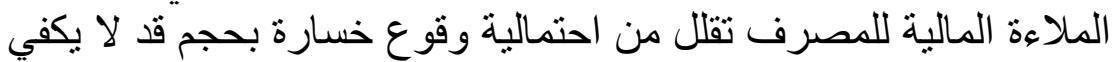

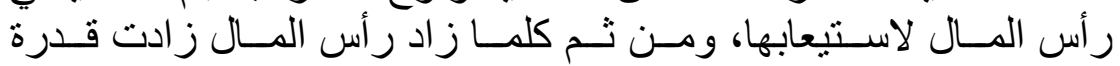
المصرف على تحمل نتائج الخسائر الكبيرة.

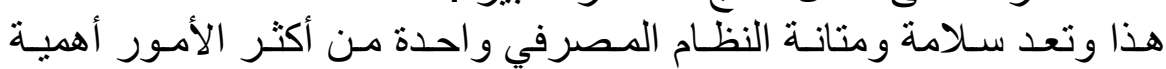

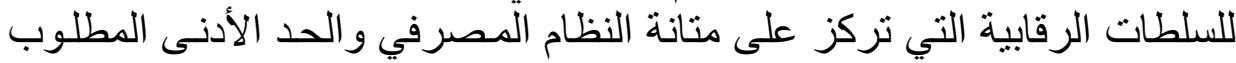
للإبقاء على متانة النظّام المصرفي.

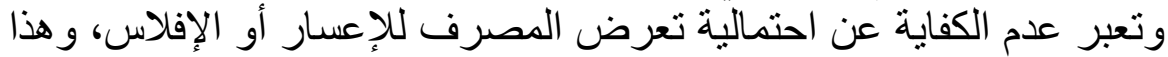

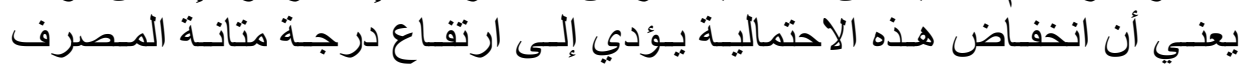


(Hasan, 2002 (H). وبهذا تعرف الكفايـة بأنها القدرة الماليـة النهائية على إعـادة

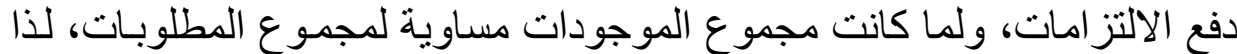

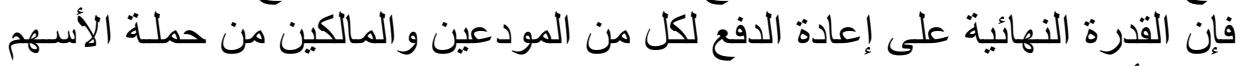

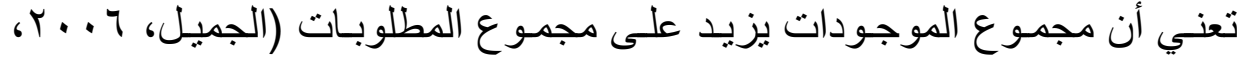

ويعد المصطلحان كفايـة رأس المـال (Capital Adequacy) و القدرة الايفائيـة

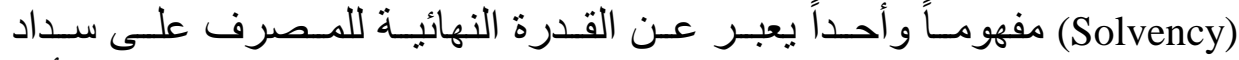

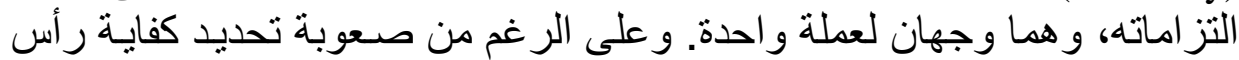

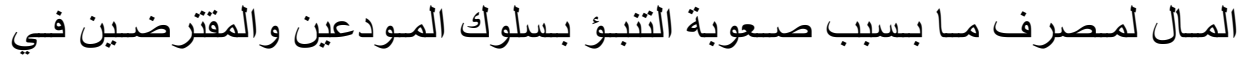
المستقبل تمكن الخبر اء من وضع عدة مؤشر ات لاحتساب مدى كفايـة رأس المـال

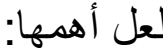

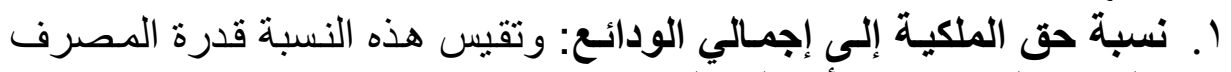

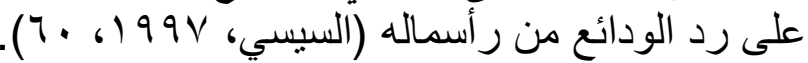

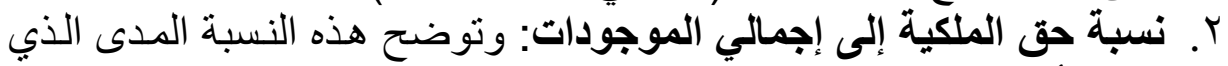

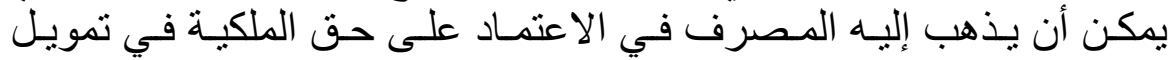

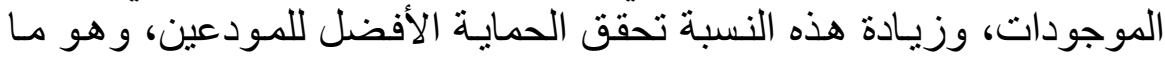

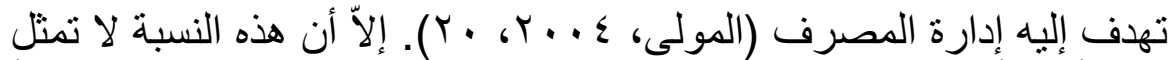

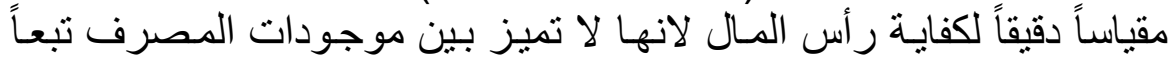
لارجة المخاطرة. r. نسبة حق الملكية إلى مجموع الموجودات ذات المخاطرة: وتعد هذه النسبة

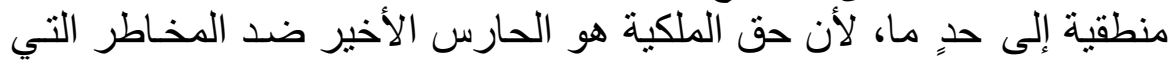
يتعرض لها المصرف في موجوداته وليس في ودائعه، فالودائع في حد ذاتها لهاتيا

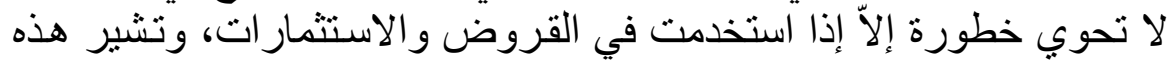

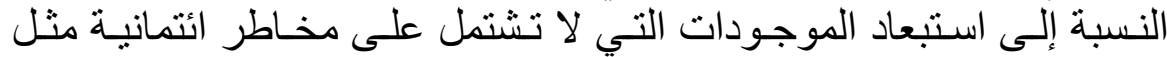

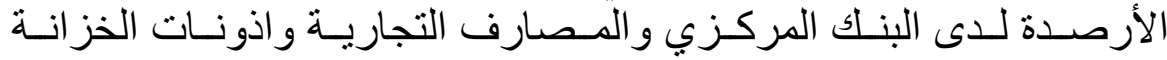

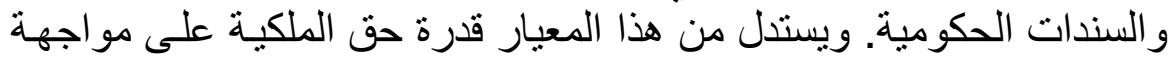

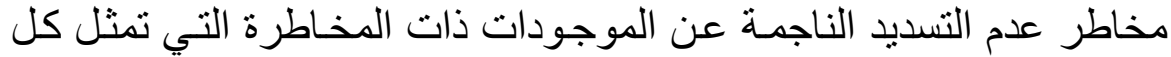

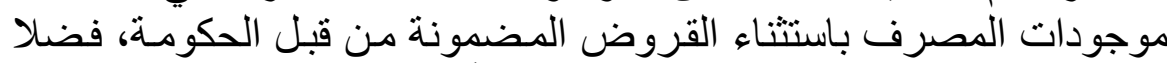

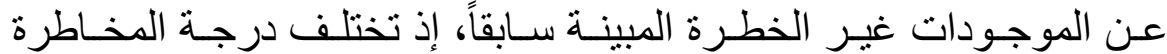

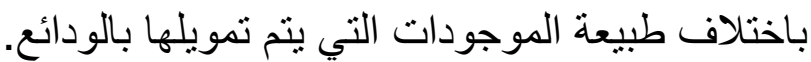

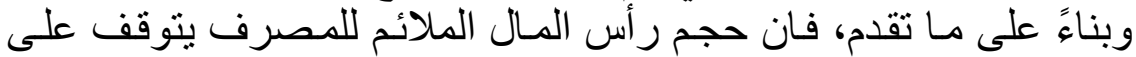

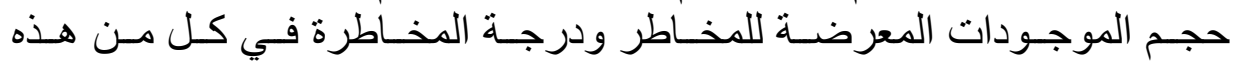

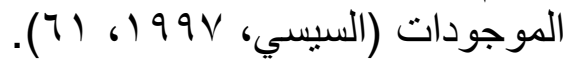

ثانياً- مقررات بازل I والانتقادات التي وجهت إلبها

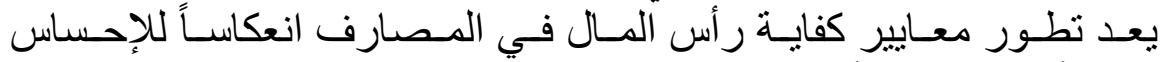

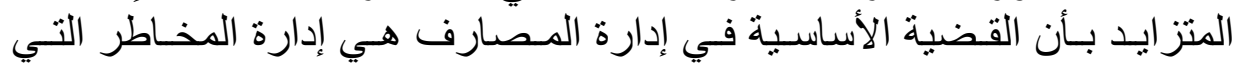




\section{محمد [ryo}

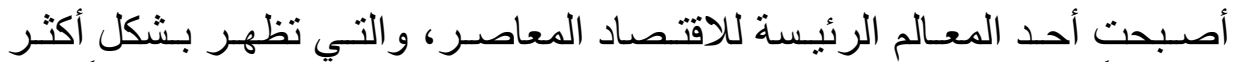

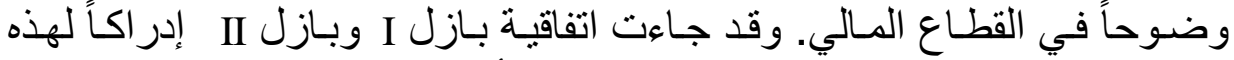

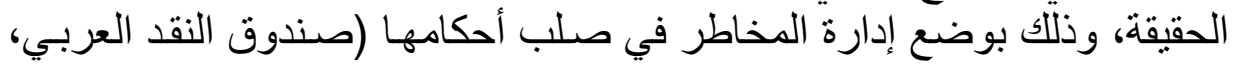

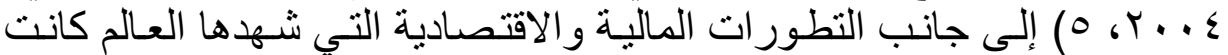

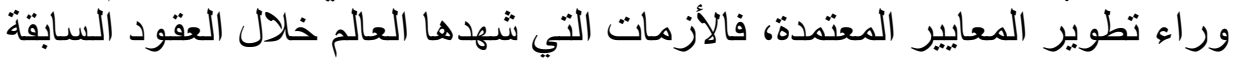

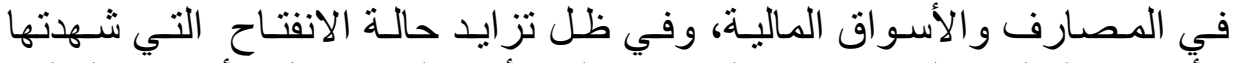

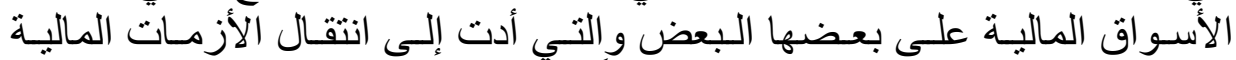

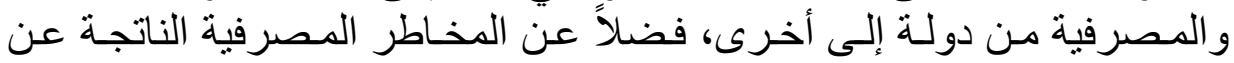

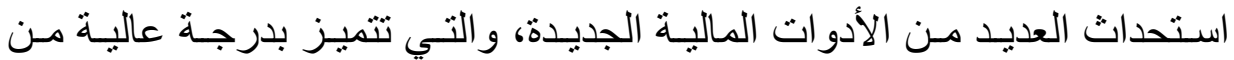

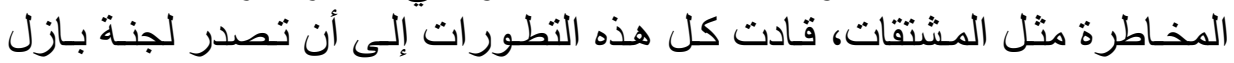

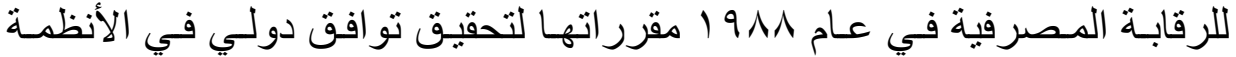

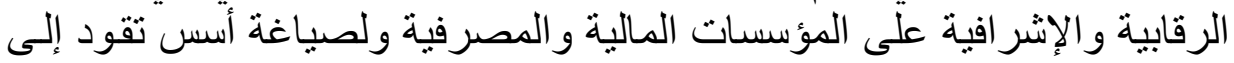
تقوية وسلامة المؤسسات المالية ودعم المنافسة العالمية وترصينها.

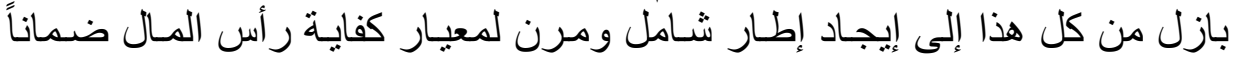

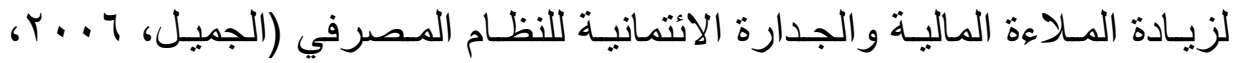

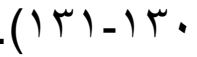

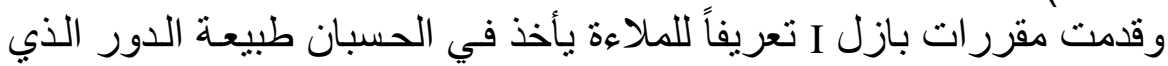

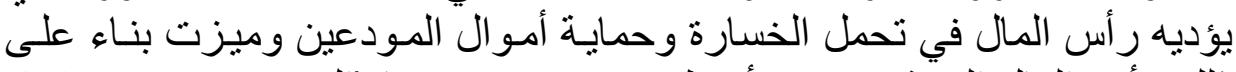

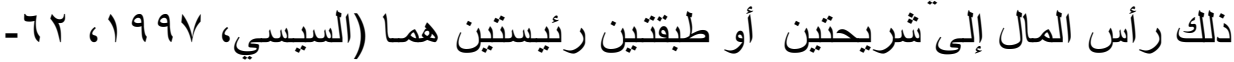

• بآ): رأس المـال الأسـاسـي: ويـضم رأس المـال المـدفوع والاحتياطيـات المعلقـة

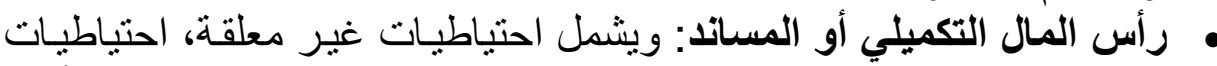

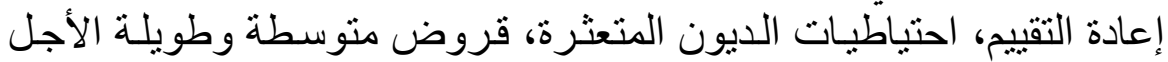

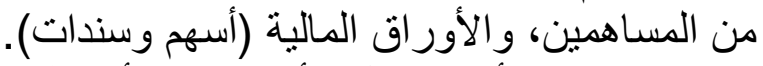

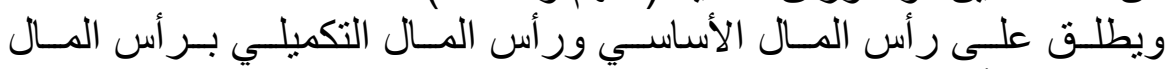

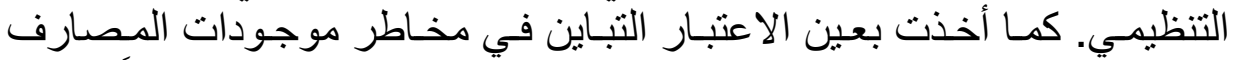

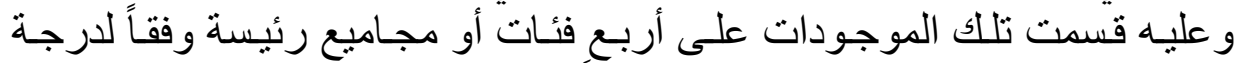

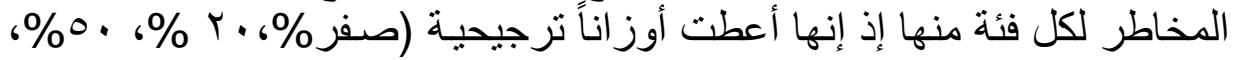

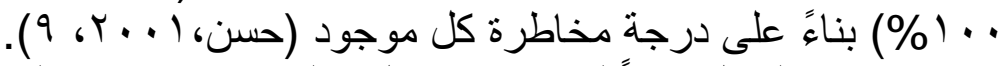

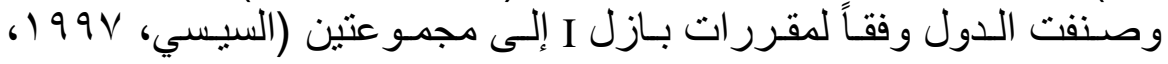

ا. الدول ذات المخاطر المتدنية: وتضم الدول الأعضاء في اللجنة وكذلك الدول

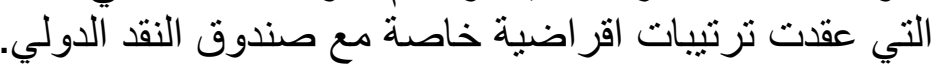

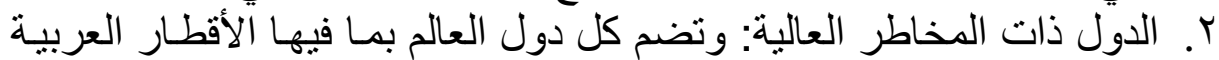

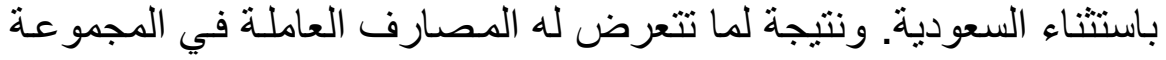


الثانية من مخاطر فقد أوصت لجنـة بـازل بضرورة زيادة رؤوس أمو الها

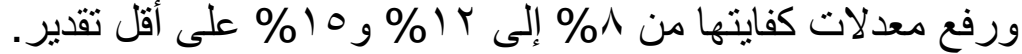

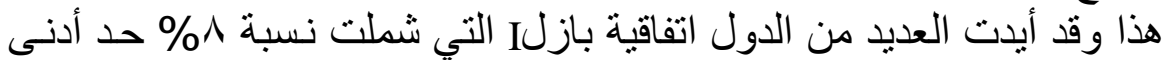

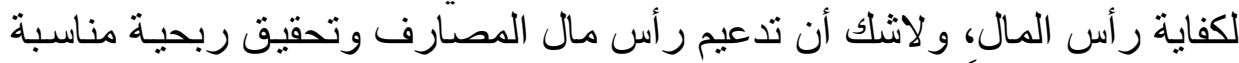

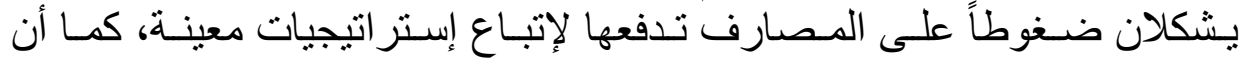

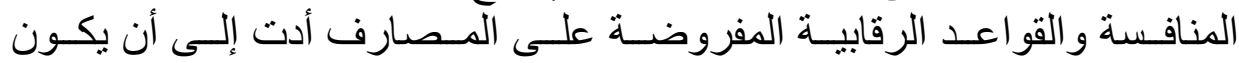

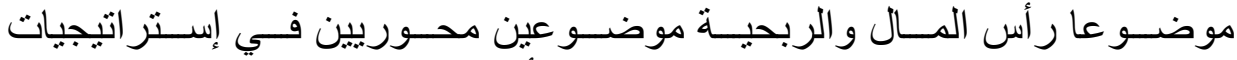

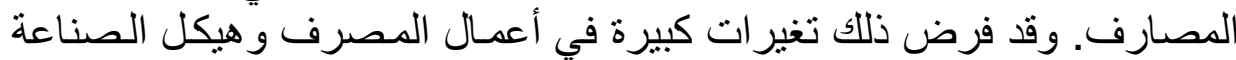

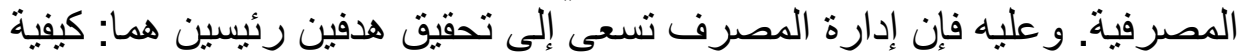

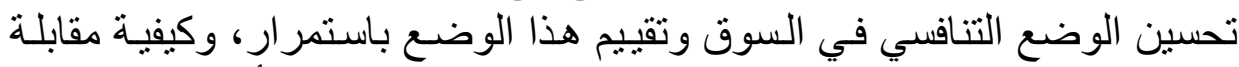

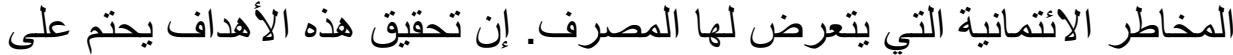

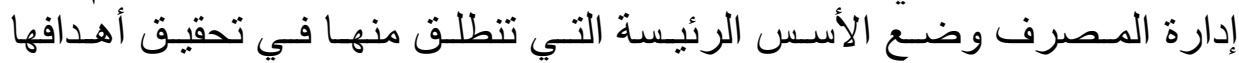

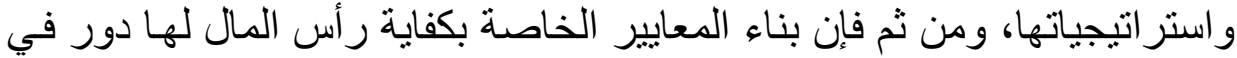

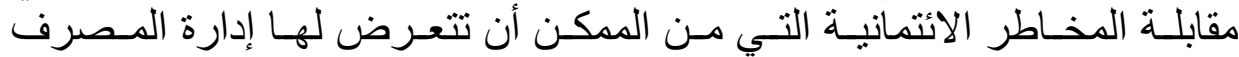

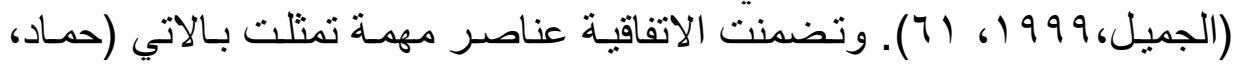

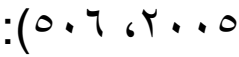

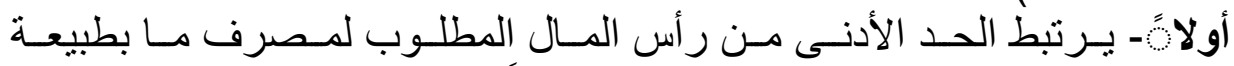

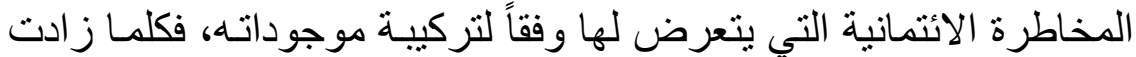

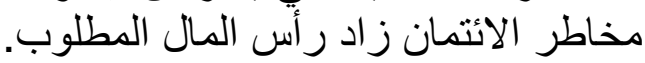

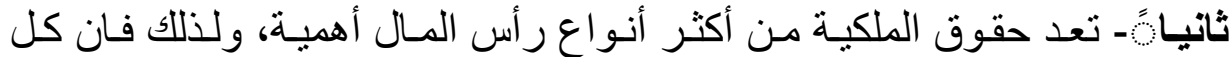

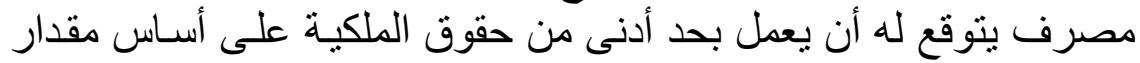

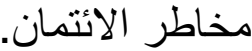

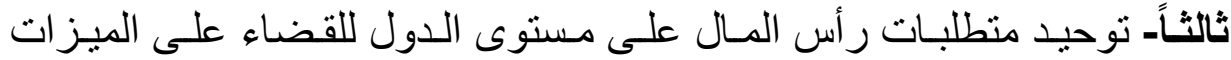

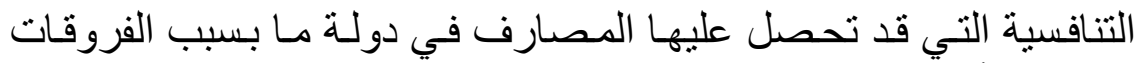
التنظيمية أو ألمحاسبية. إلاّ أن فاعلية وأهمية هذا المعيار بوصفه وسيلة للتأكد من أن منطلبات رأس

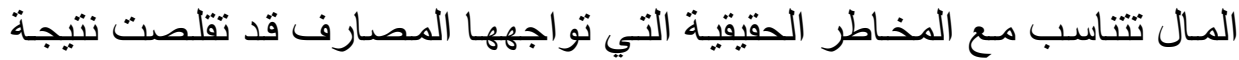

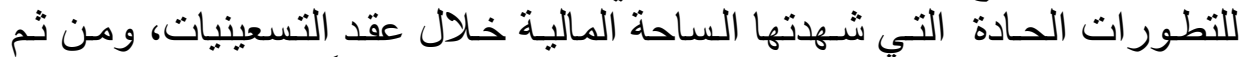

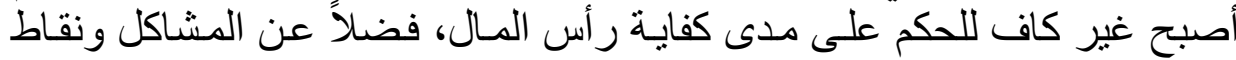

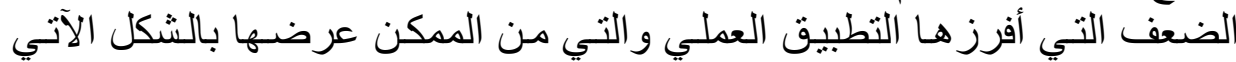

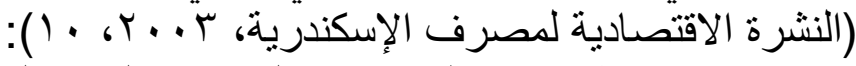

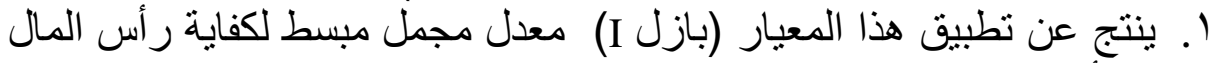

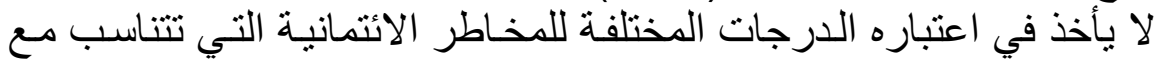

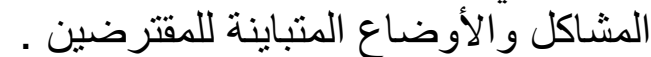

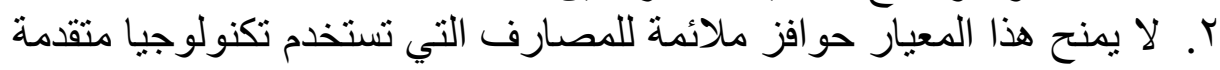

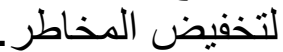




\section{محمد [ry}

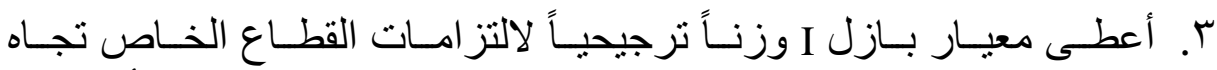

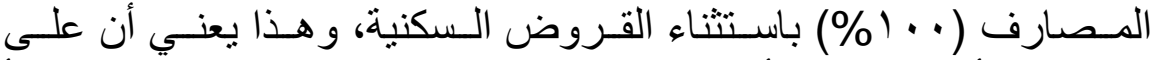

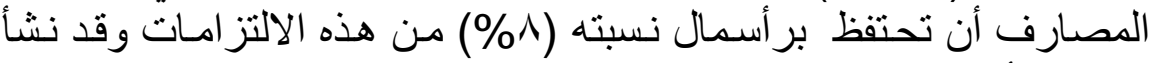

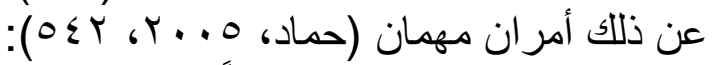

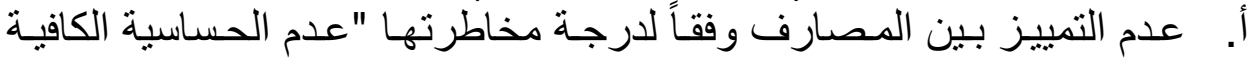

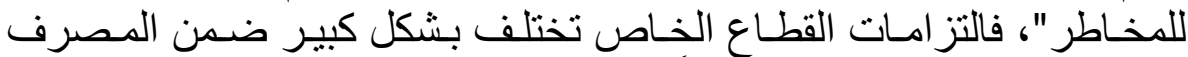

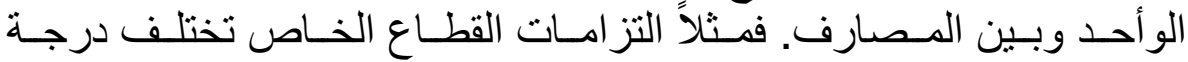

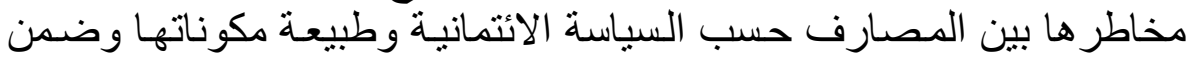

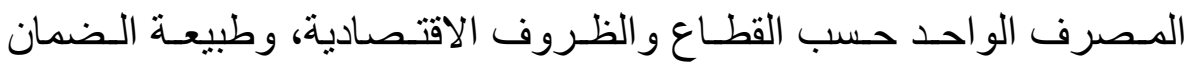

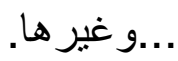
ب. قيام العديد من المصارف بنقل الموجودات ذات المخاطر إلى خـارج الميز انية المية

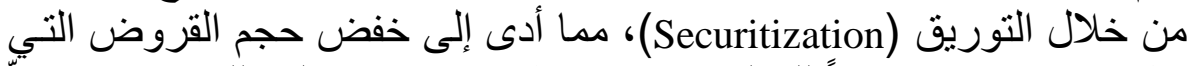

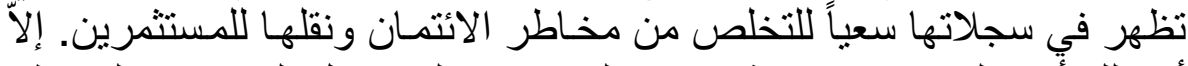

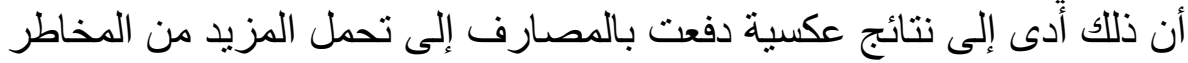

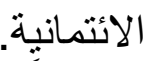

فضلاً عما ما سبق فان معيار بازل I لكفاية رأس المال لم بأخذ في الحسبان

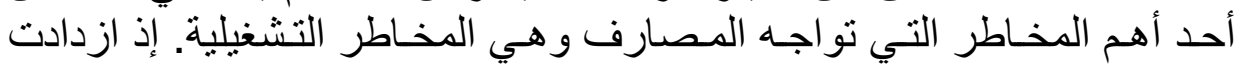

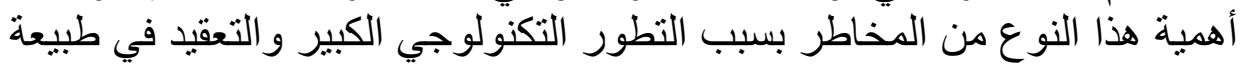

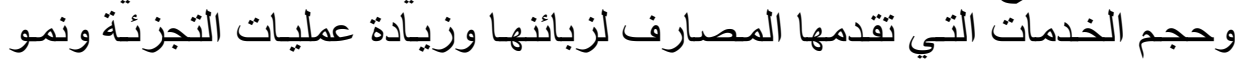

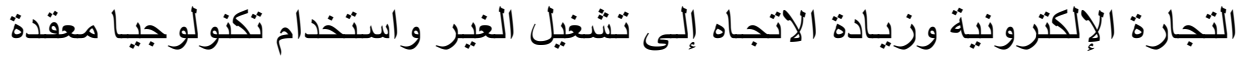

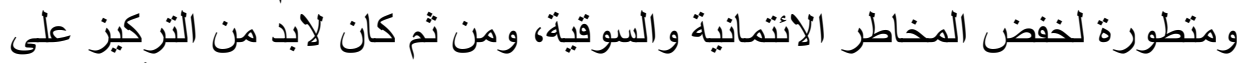

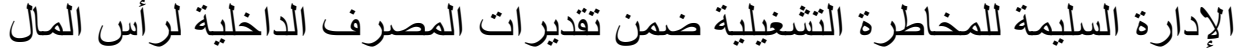

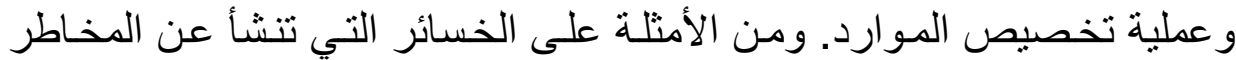

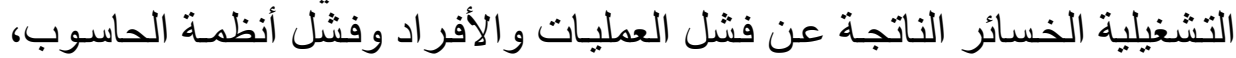

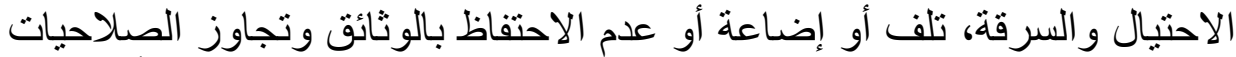

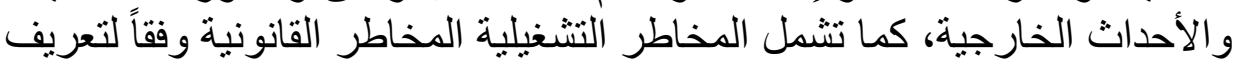

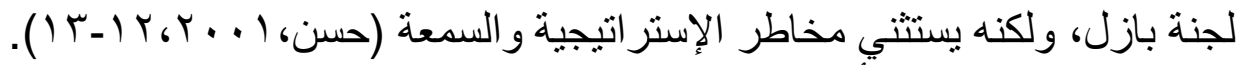

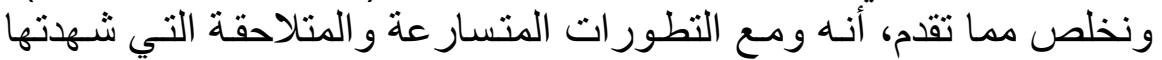

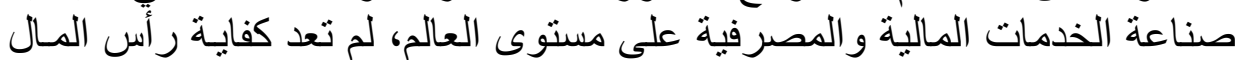

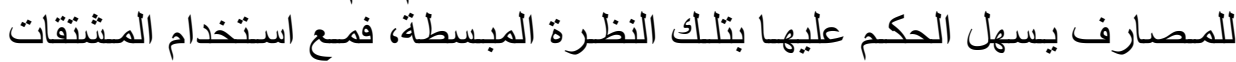

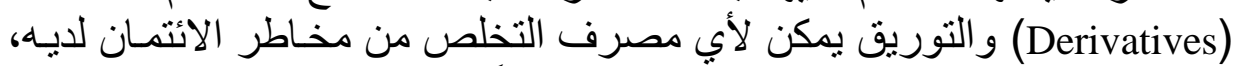

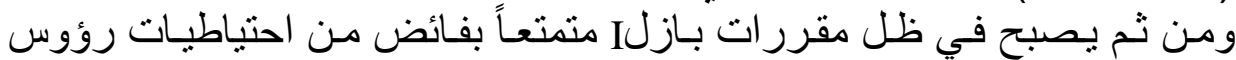

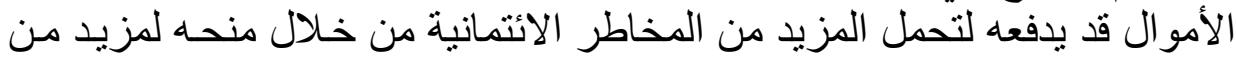

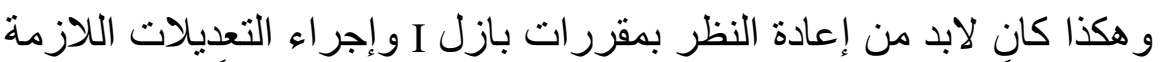

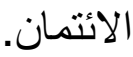

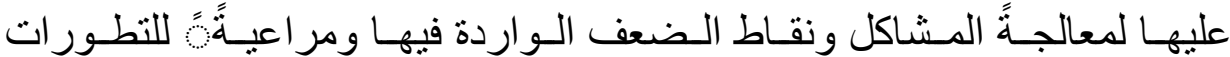




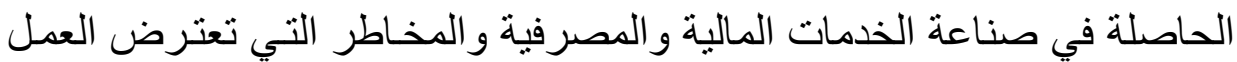
المصرفي، ولاسيما المخاطر الائتمانية ومخاطر السوق والية والمخاطر التشغيلية.

$$
\text { تالثاً. مقررات بازل II - II أهدافها - ركائزها }
$$

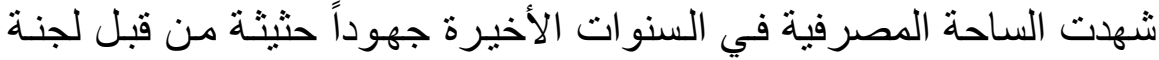

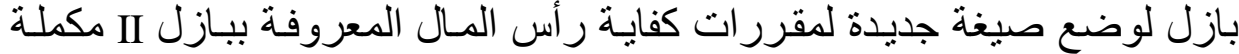

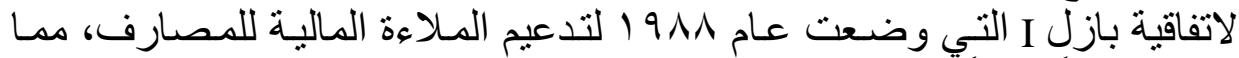

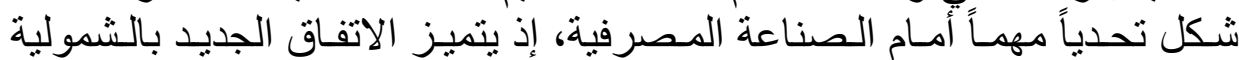

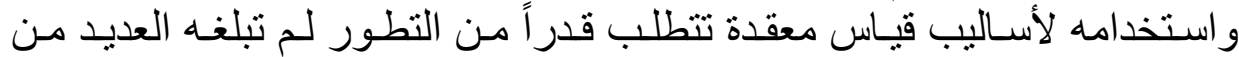

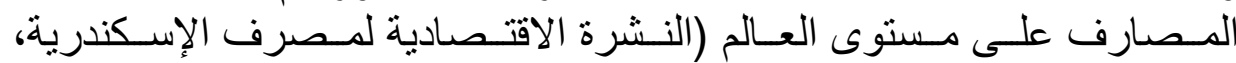

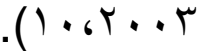
ويتكون رأس المال التنظيمي في ظل المقرر ات الجديدة من ثلاث شر ائح من رأس المال تثمثل بالاتي (Greuning, 2000, 104-105):

Tier 1 capital الثريحة الأولى من رأس المال

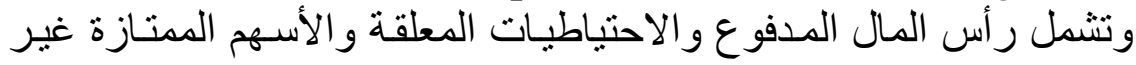

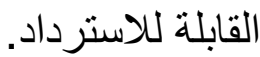

\section{Tier 2 capital}

الثريحة الثانية من رأس المال

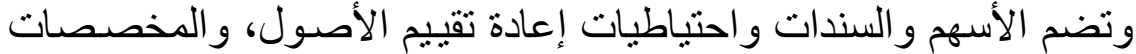

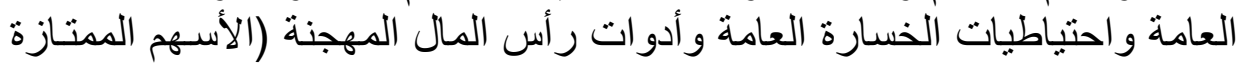

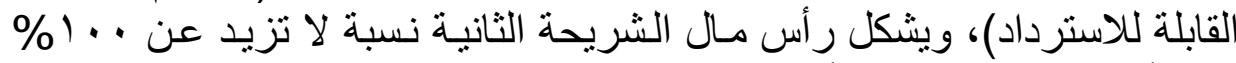

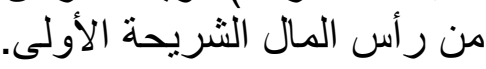

Tier 3 capital

الثريحة الثالثة من رأس المال

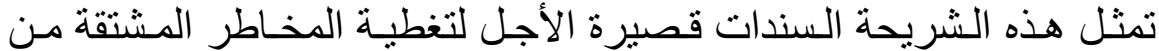

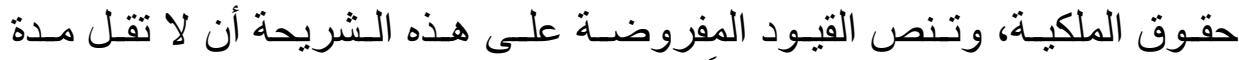

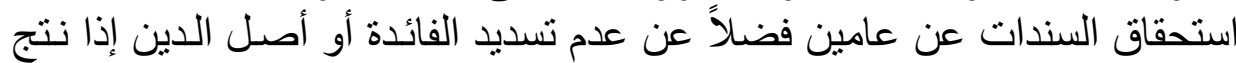

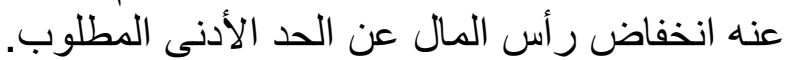

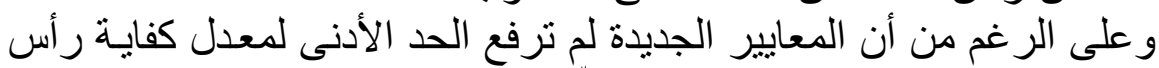

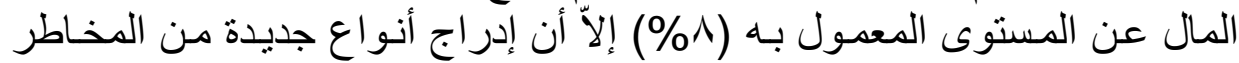

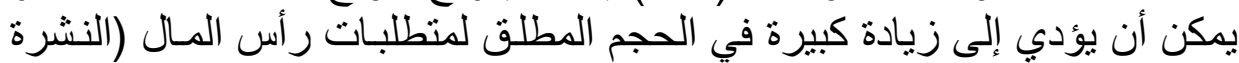

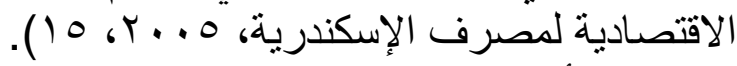

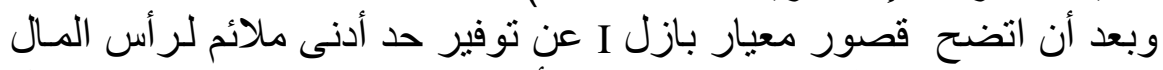

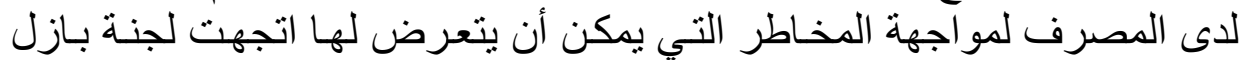
إلى التفكير في معايير جديدة لقياس كفاية رأس المال، فقد أصبحت تلك الك المخاطر 


\section{محمد [rq9}

لاتقتصر على المخاطر الائتمانية فحسب، وإنما امتدت لتتثمل العديد من المخاطر

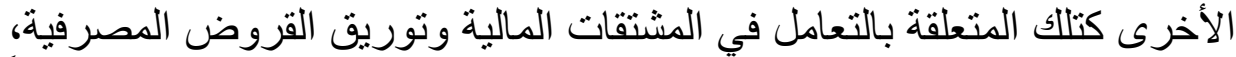

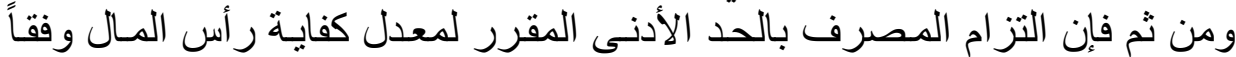

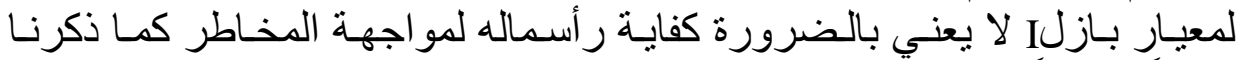

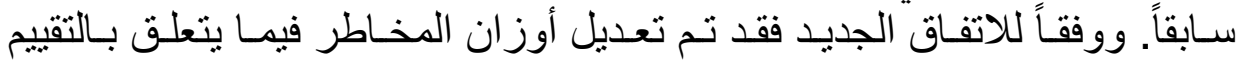

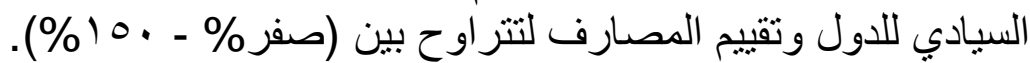

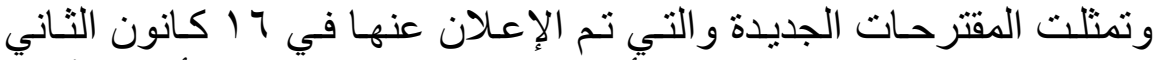

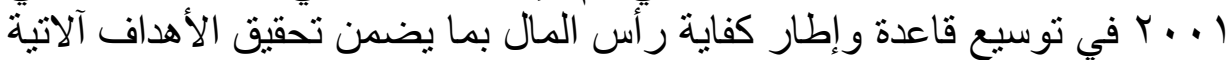

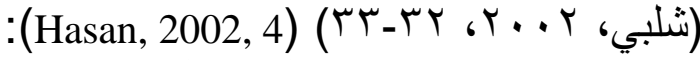
1. ت. تعزيز سلامة ومتانة النظام المالي و المصرفي.

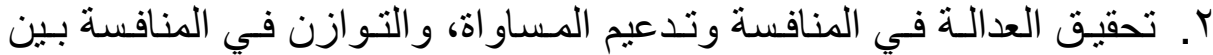

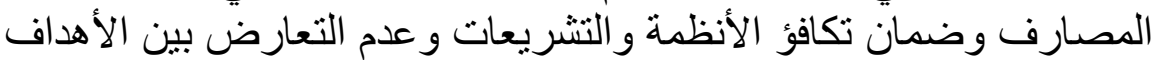

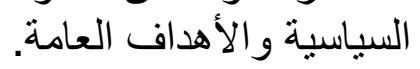
r. تغطية شاملة للمخاطر التي تواجة التهاه المصارف.

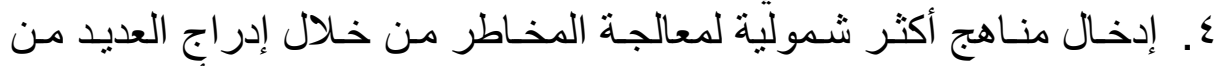

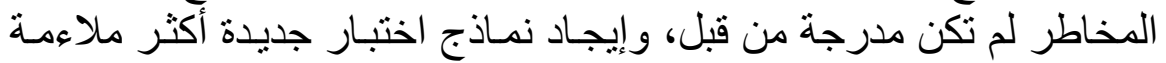

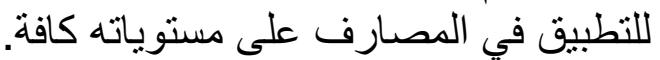

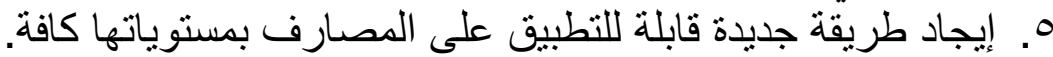

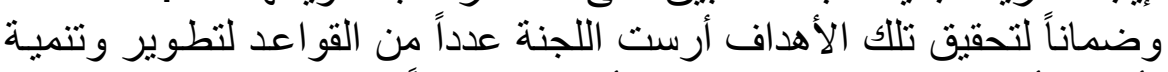

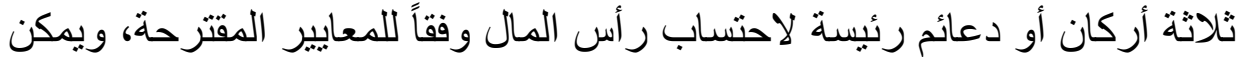
عرض هذه الركائز على النحو الآتي:

Minimum Capital الركيزة الأولسى: المتطلبـات الدانيا لكفايـة رأس المسال

\section{Requirements}

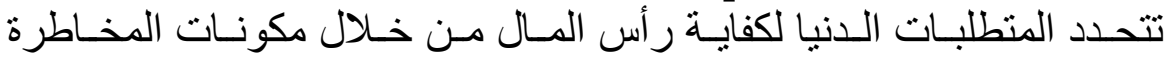

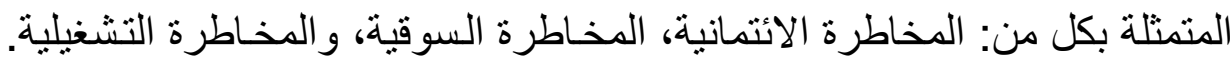

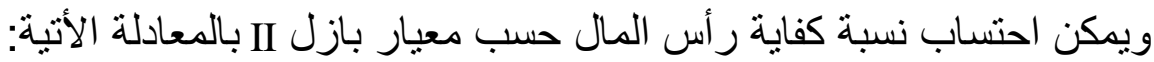
نسبة كفاية رأس المـال = رأس المـال / مخاطر الايتمان + مخاطر السوق + مخاطر التشغيل

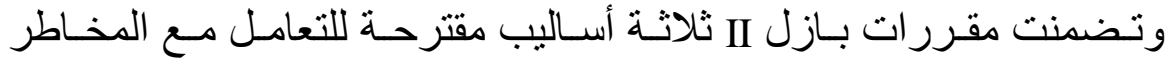

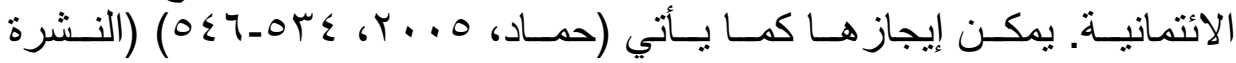

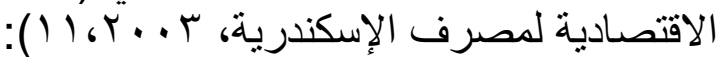

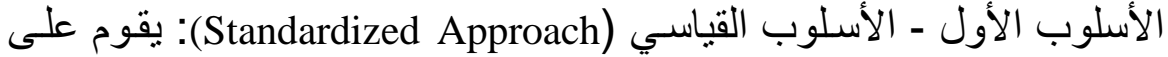

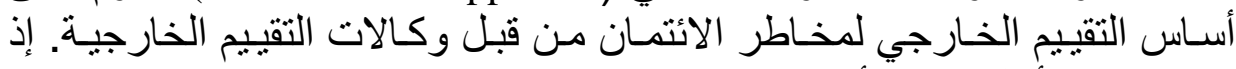

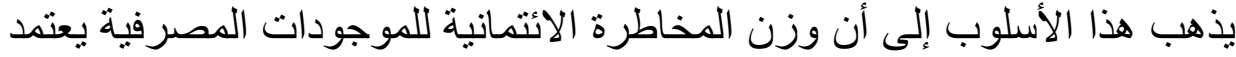

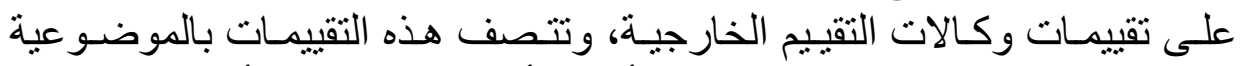

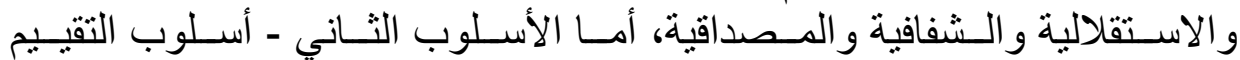


الداخلي (Internal Rating Based Approach IRB) ويعد طريقة مبسطة تعتمد

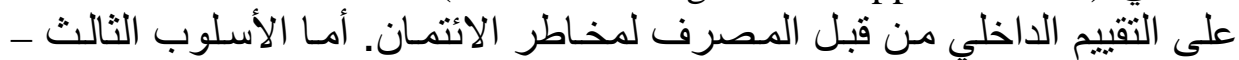

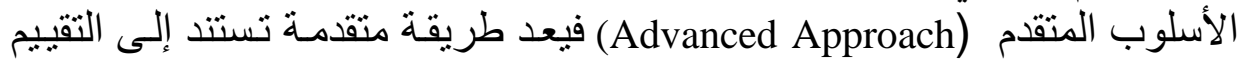
الداخلي من قبل المصرف لمخاطر الائتمان.

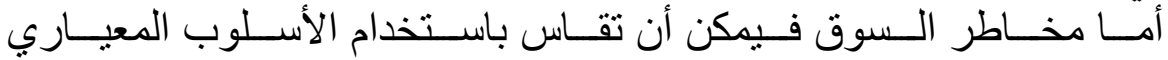
أو باستخدام نماذج تقييم متطورة من قبل المبل المصارف (Standardized Approach)

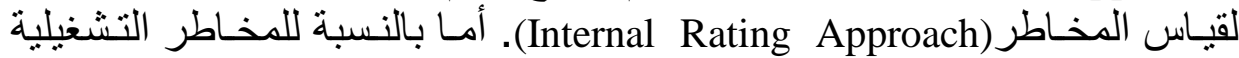

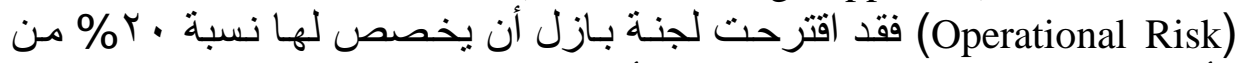

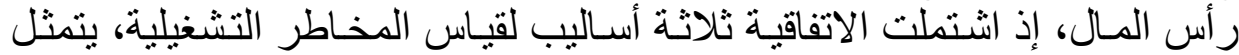

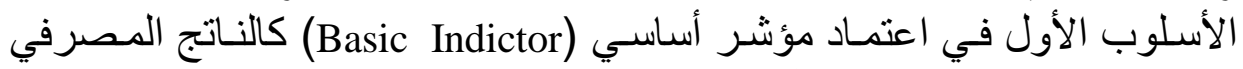

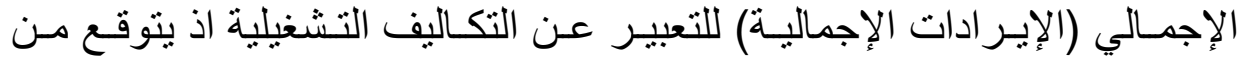

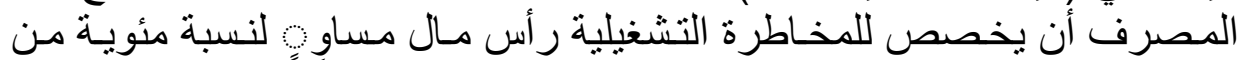

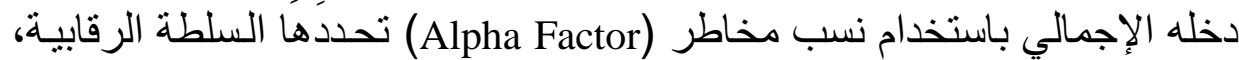

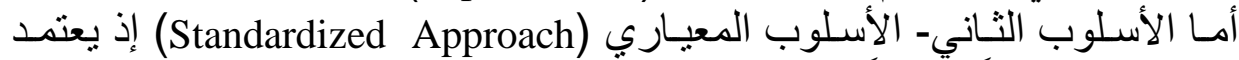

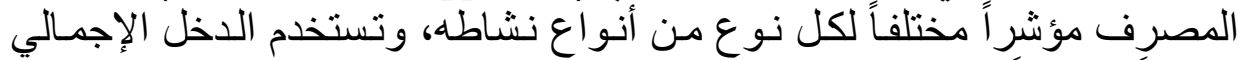

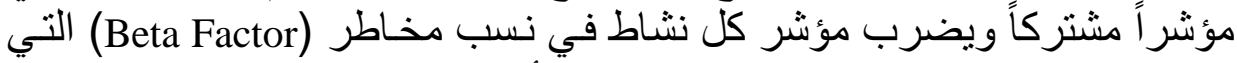

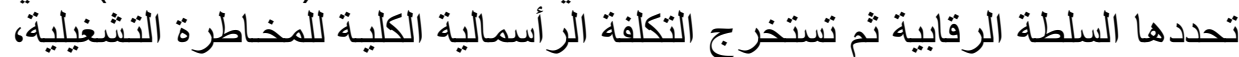

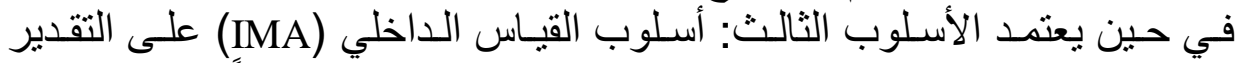

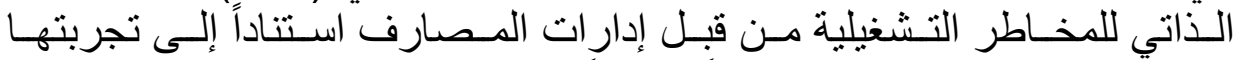

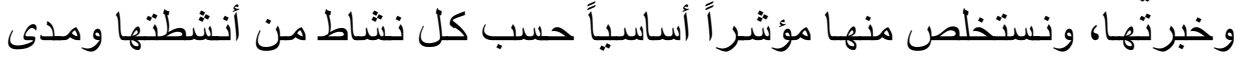

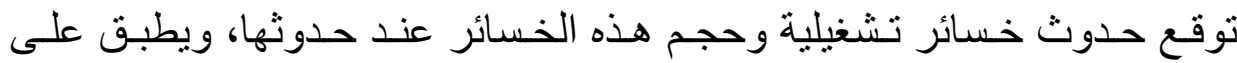

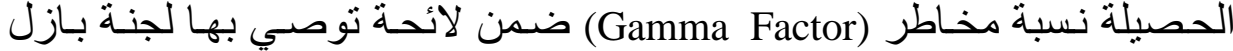

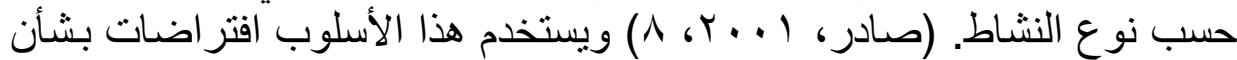

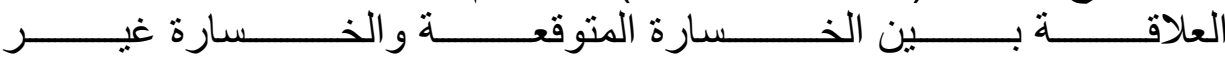

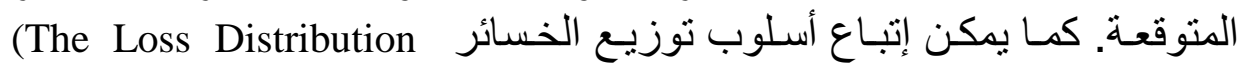
Approach (LDA))

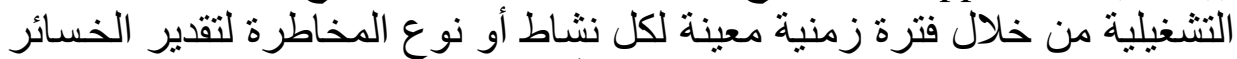

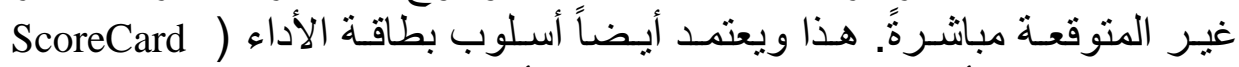
Approach

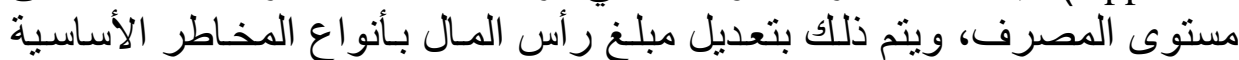

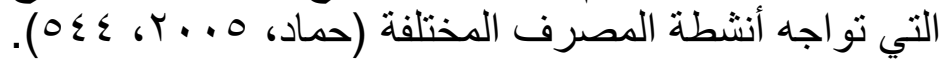

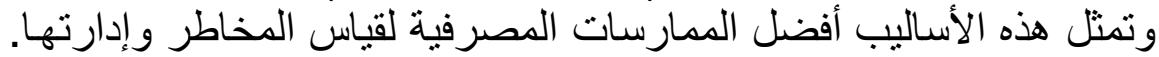

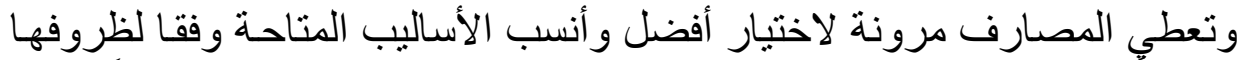

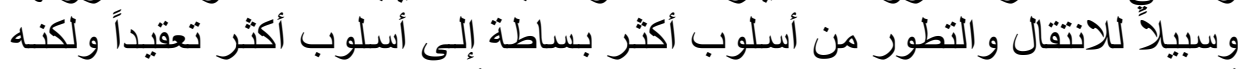

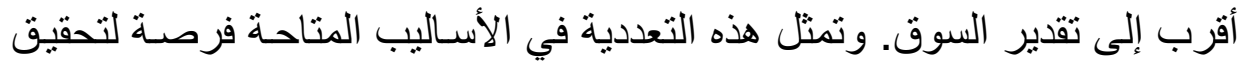

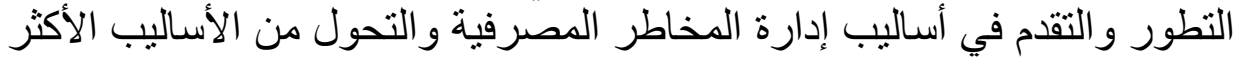

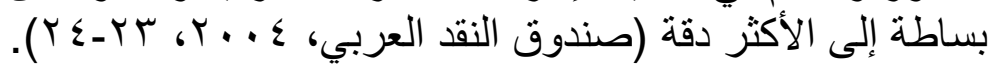




\section{[rvi] [حمد}

Supervisory Review of الركيزة الثانية: الرقابة الإثرافية على المصارف

Capital Adequacy

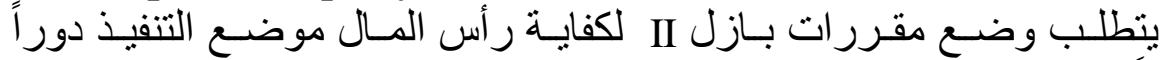

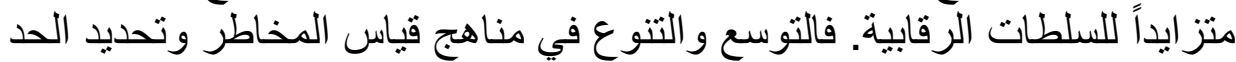

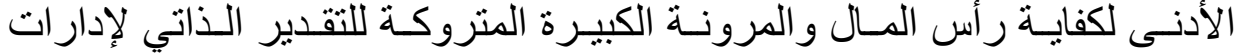

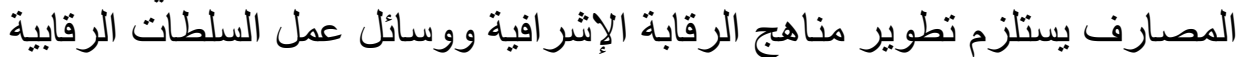

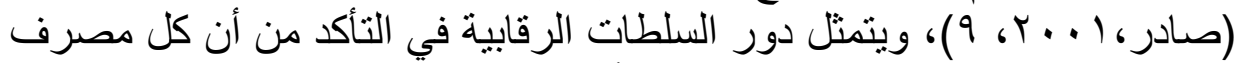

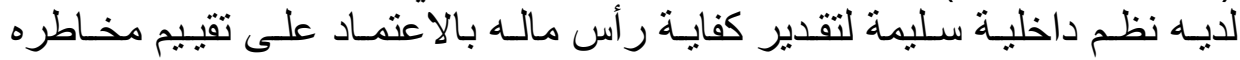

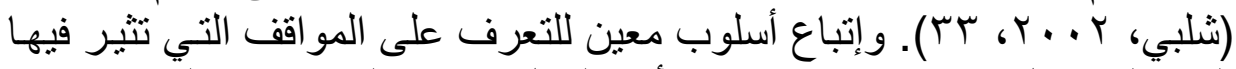

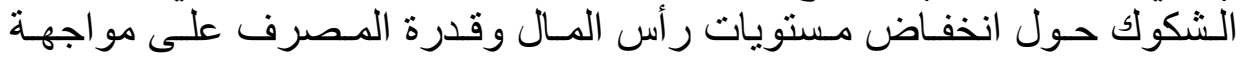

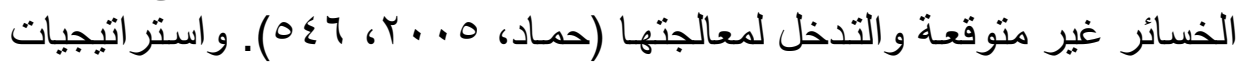

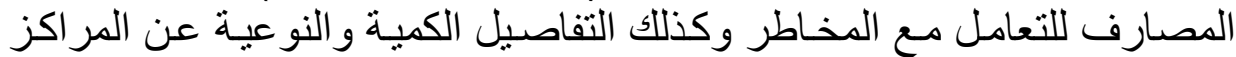

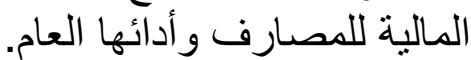

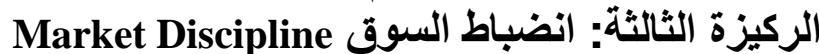

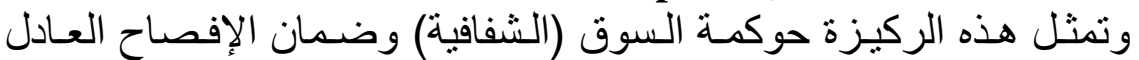

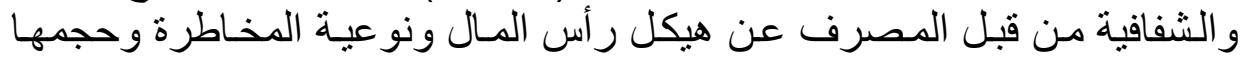

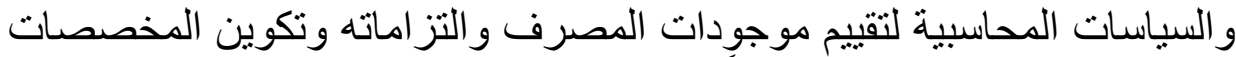

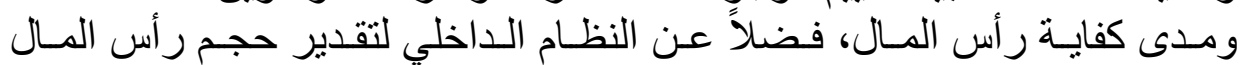

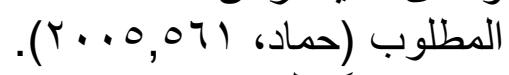

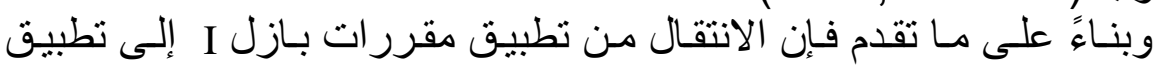

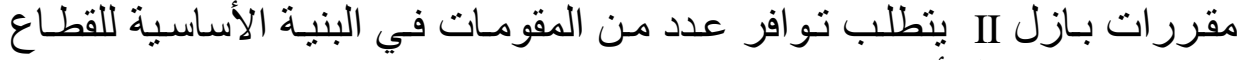

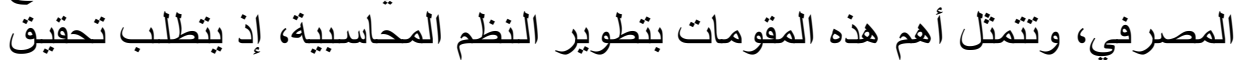

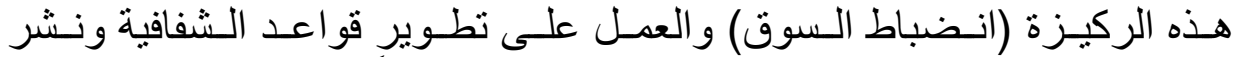

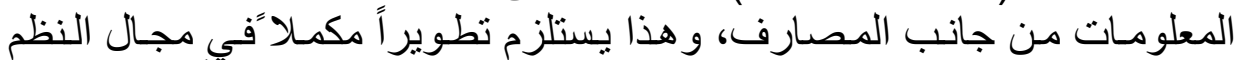
المحاسبية المطبقة والإفصاح عن البيانات و التقارير المالية، فضلاًلًا عن تطوير

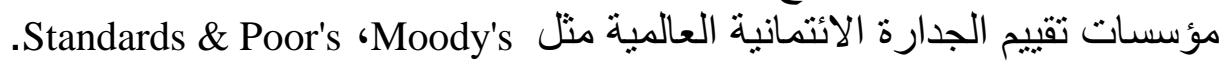

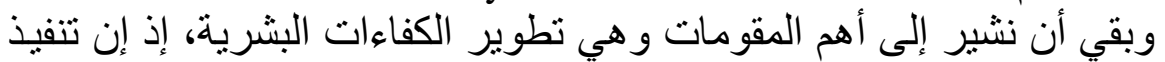
أحكام اتفاقية بازل II ينطلب نو الفية عالية من الكفاءات البشرية سواء في التهاء التحليل

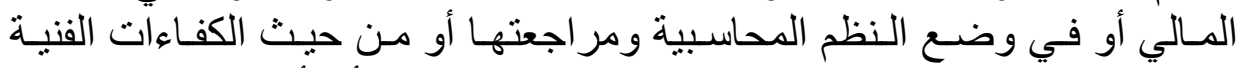

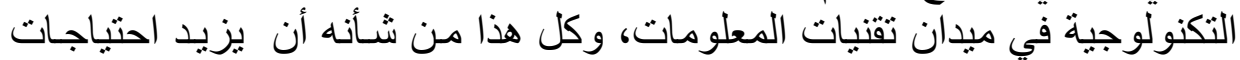

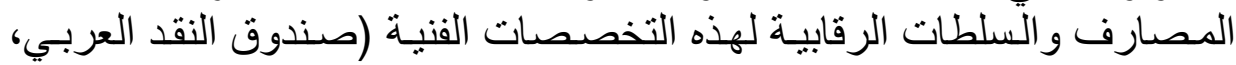

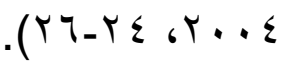

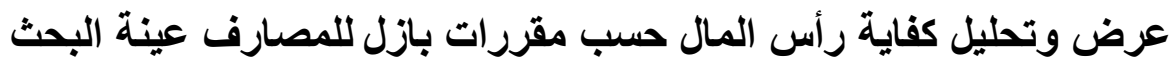

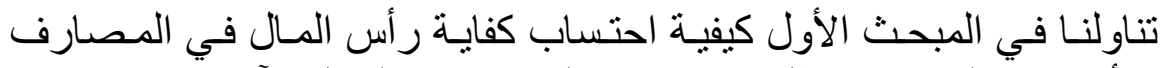

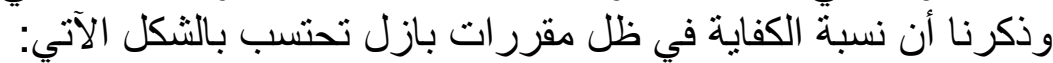
نسبة كفاية رأس المال = رأس المال/ الموجودات المرجدة بالئل بالمخاطر 


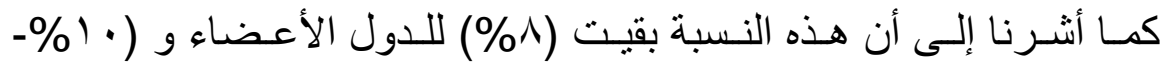

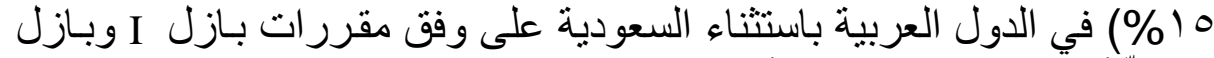

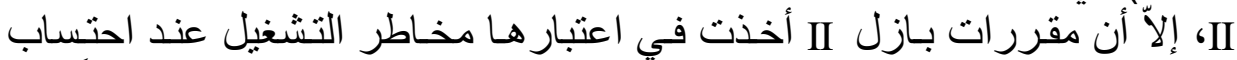

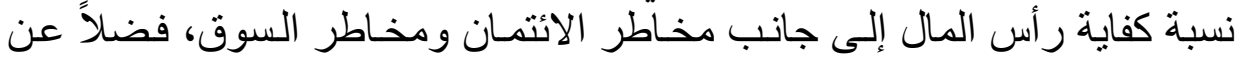

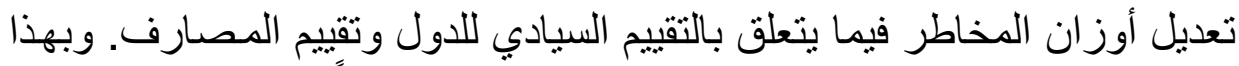

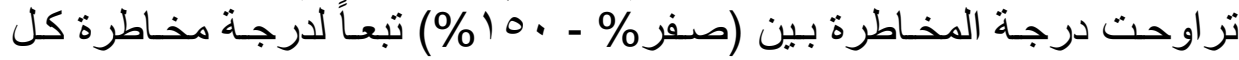

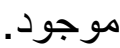

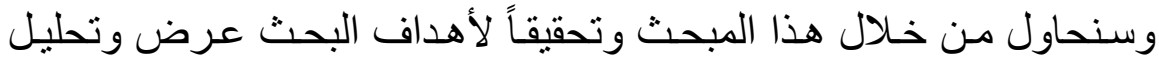

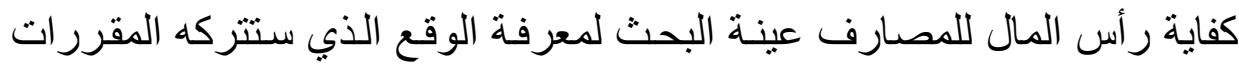

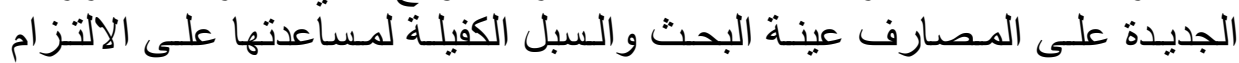

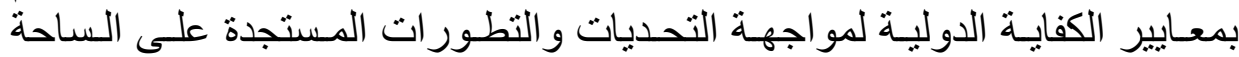

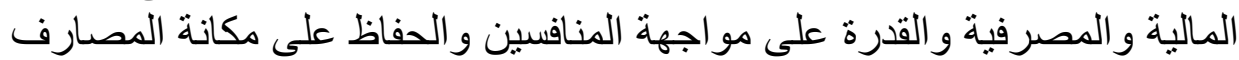

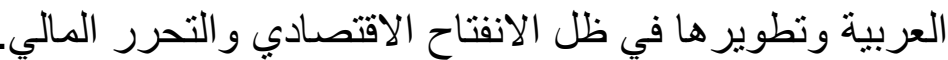

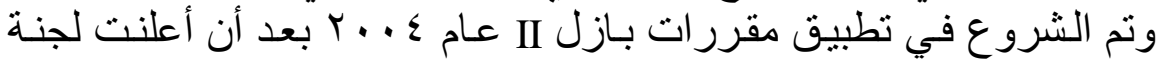

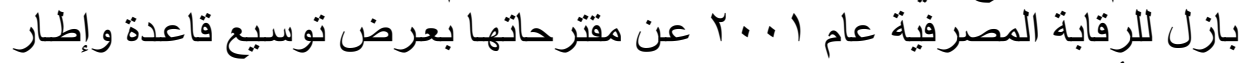

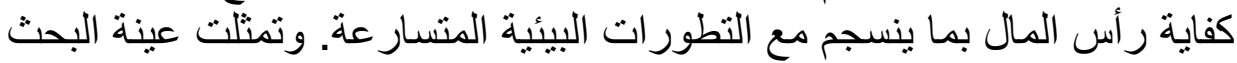

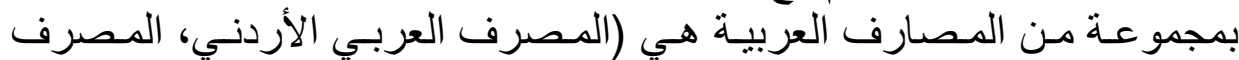

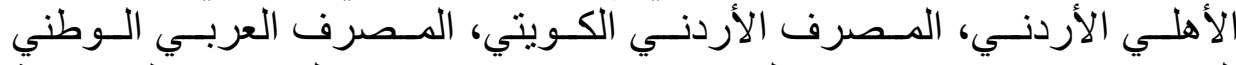

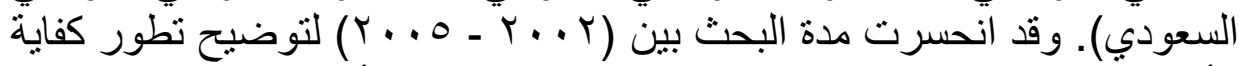

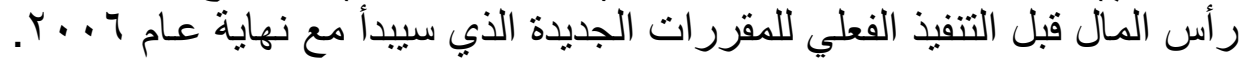
وفيما يأتي عرض وتحليل نسب كفاية رأس المال للمصارف عينة البحث:

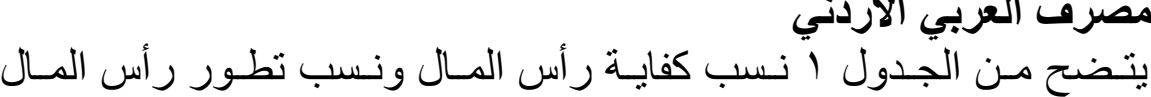

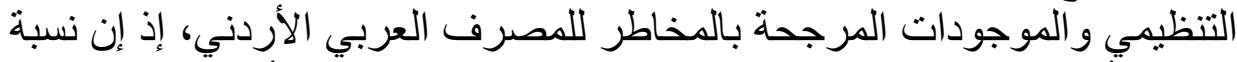

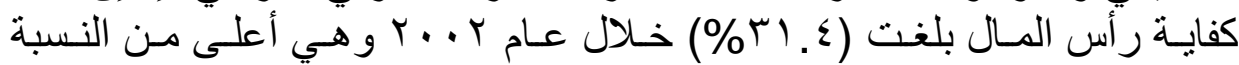

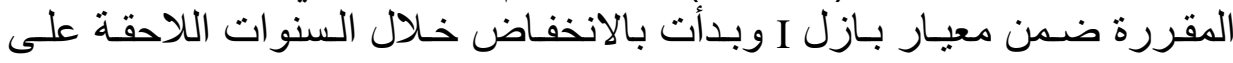

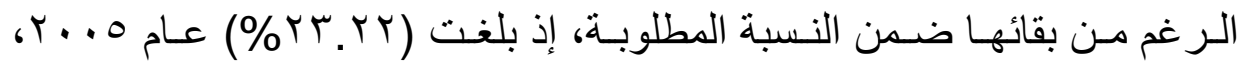

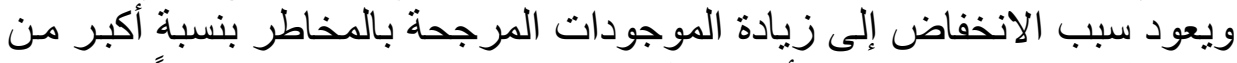

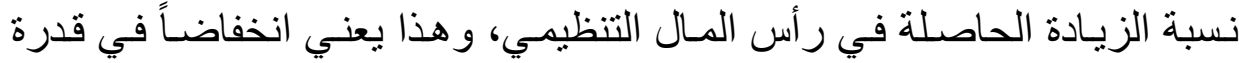

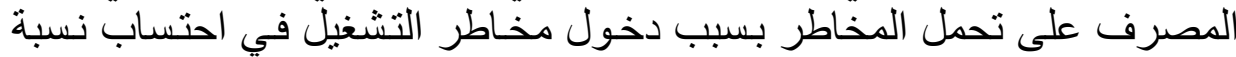

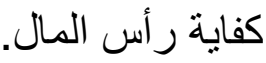

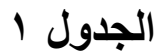

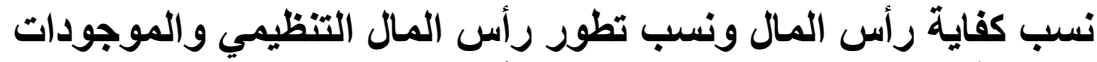

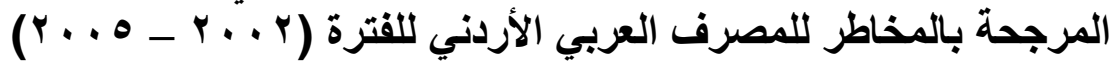
(المبالغ بآلاف الدنانير الأردنية) 
محمد [YrT

\begin{tabular}{|c|c|c|c|c|}
\hline Y.. o & $r \ldots \varepsilon$ & $r \cdot r$ & $r \ldots r$ & البنود/السنوات \\
\hline 49903 & 42428 & 37671 & 33583 & رأس المال \\
\hline 17.62 & 12.63 & 12.17 & & نسبة نمو رأس المالر\% \\
\hline 214913.9 & 159864.4 & 140197.2 & 106952.2 & الموجودات المرجحة بالمخاطر \\
\hline 34.44 & 14.03 & 31.08 & ---- & نسبة نمو الموجودات المرجحة بالمخاطر \% \\
\hline 23.22 & 26.54 & 26.87 & 31.4 & نسبة كفاية رأس الماله\% \\
\hline
\end{tabular}

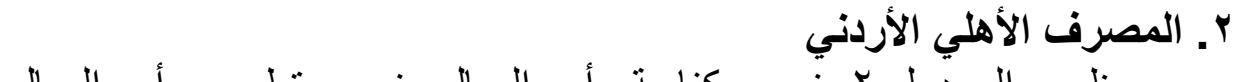

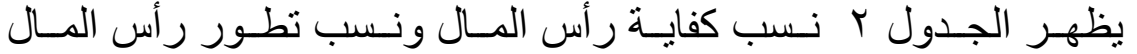

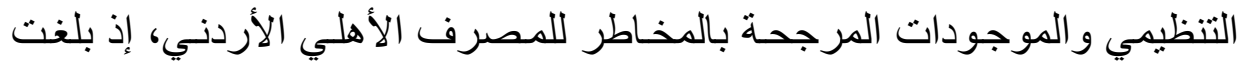

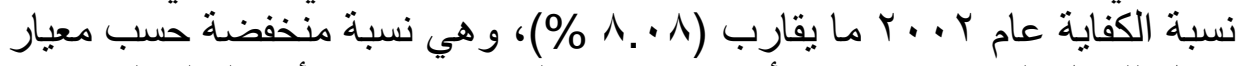

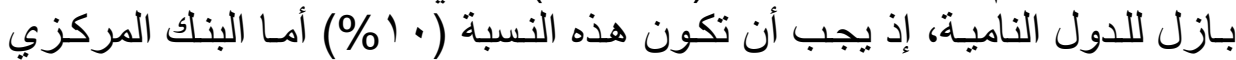

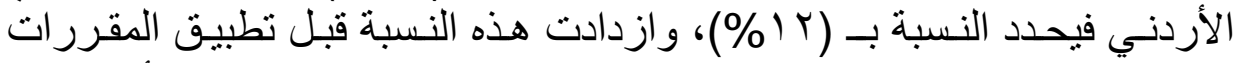

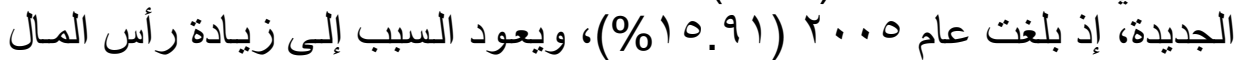

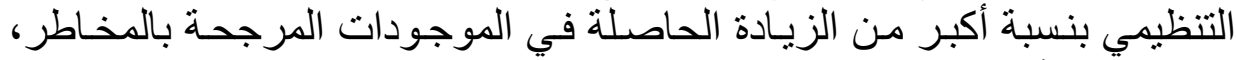

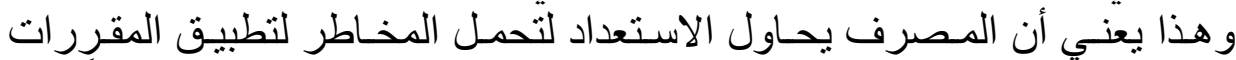

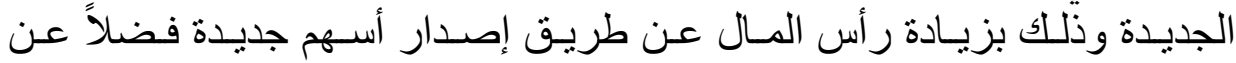

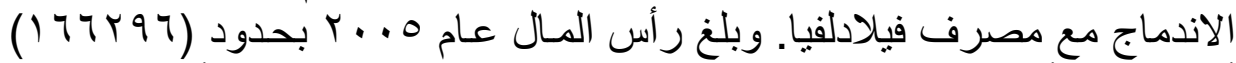

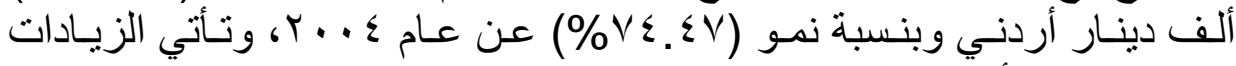

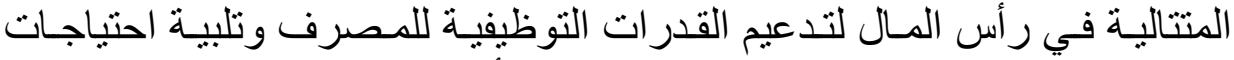
التوسع الإقليمي ومتطلبـات بـازل II لكفايـة رأس المـال، ومـن ثم زيسادة قدرة المصرف على تحمل المخاطر.

\begin{tabular}{|c|c|c|c|c|}
\hline مبالغ & 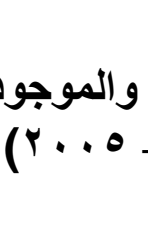 & ة & تطور الجدول أسر الأردني & 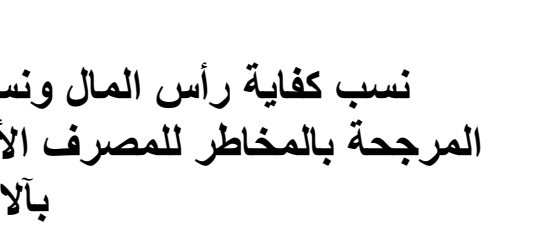 \\
\hline$r \ldots \theta$ & $r \ldots \varepsilon$ & $r \ldots r$ & $r \ldots r$ & البنود/السنوات \\
\hline 166296 & 95314 & 70962 & 61961 & رأس المال \\
\hline 74.47 & 34.32 & 14.53 & ------ & نسبة نمو رأس المال٪\% \\
\hline 1045229 & 844982.3 & 736120.3 & 766844.1 & الموجودات المرجحة بالمخاطر \\
\hline 23.70 & 14.79 & -4.01 & ------ & نسبة نمو الموجودات المرجحة بالمخاطر\% \\
\hline 15.91 & 11.28 & 9.64 & 8.08 & نسبة كفاية رأس المال\%\% \\
\hline
\end{tabular}


نلاحظ مـن الجدول ب نـسب كفايـة رأس المـال ونسـب تطور رأس المـال

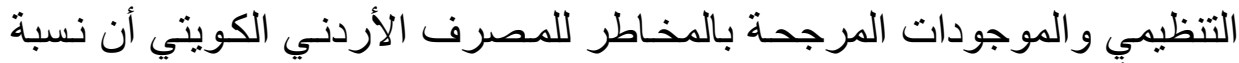

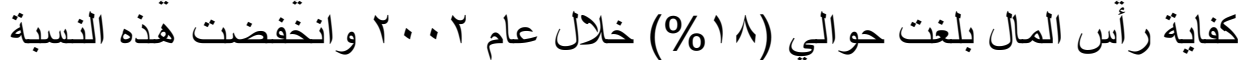

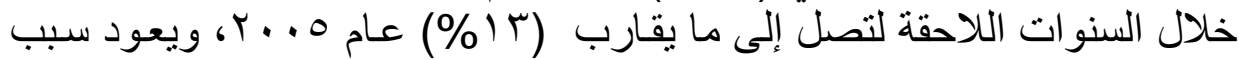

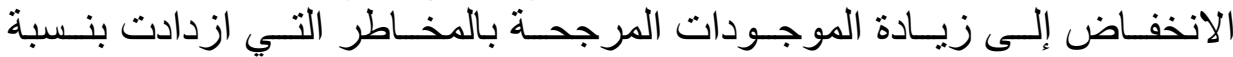

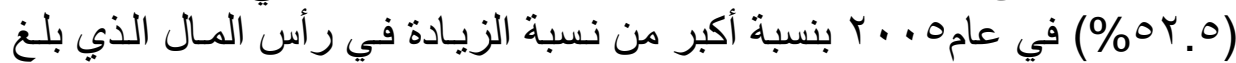

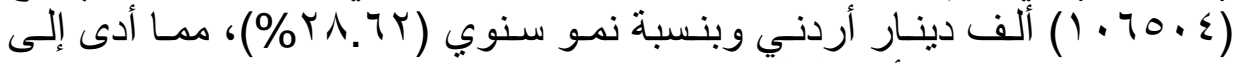
انخفاض نسبة كفاية رأس المال للمصرف. أل أن

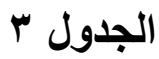

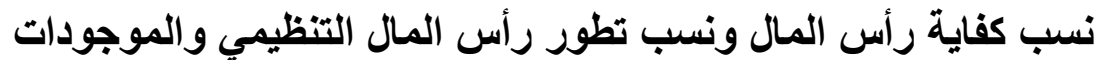

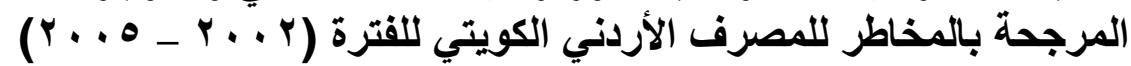

\begin{tabular}{|c|c|c|c|c|}
\hline$r \ldots o$ & $Y \ldots \varepsilon$ & $r \ldots r$ & $r \ldots r$ & البنود/السنوات \\
\hline 106504 & 82802 & 68553 & 58010 & رأس المال \\
\hline 28.62 & 20.79 & 18.17 & & نسبة نمو رأس المال \% \\
\hline 811150 & 531804.8 & 439442.3 & 320497.2 & الموجودات المرجحة بالمخاطر \\
\hline 52.53 & 21.02 & 37.11 & ---- & 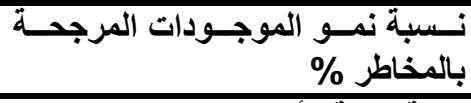 \\
\hline 13.13 & 15.57 & 15.6 & 18.1 & نسبة كفاية رأس المال \% \\
\hline
\end{tabular}

ع. المصرف العربي الوطني السعودي

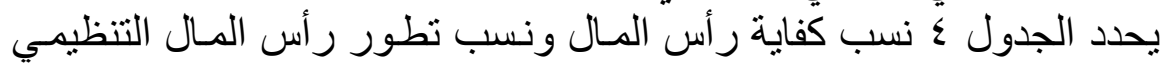

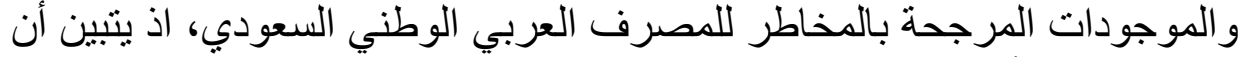

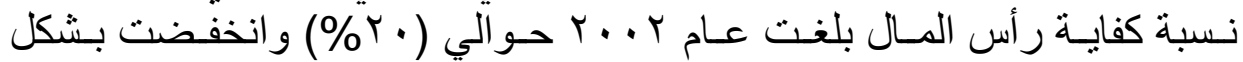

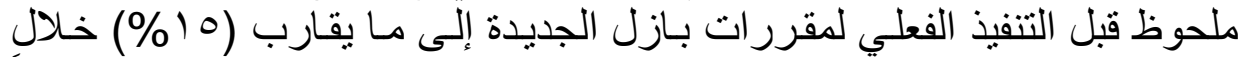

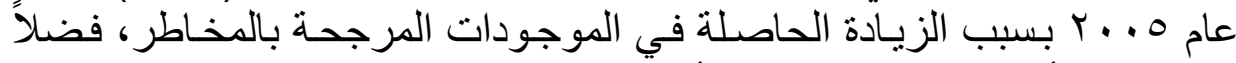

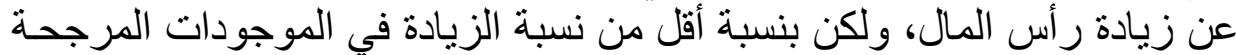
بالمخاطر، مما أدى إلى انخفاض نسبة كفاية رأس المال. 
محمد [rvo]

نسب كفاية رأس المال ونسب تطور رأس المال التنظيمي والموجودات المرجحة

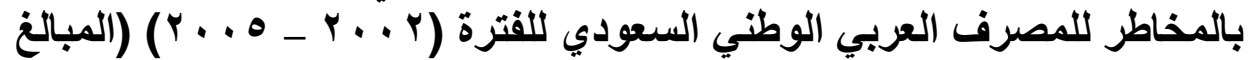
بآلاف ألريالات السعودية البية)

\begin{tabular}{|c|c|c|c|c|}
\hline$r \ldots o$ & $r \ldots \varepsilon$ & $r \ldots r$ & $r \ldots r$ & البنود/السنوات \\
\hline 6902147 & 5393044 & 4255902 & 3682620 & رأس المال \\
\hline 27.98 & 26.72 & 15.57 & & نسبة نمو رأس المال \% \\
\hline 45237450 & 33873903 & 22284881 & 18734159 & الموجودات المرجحة بالمخاطر \\
\hline 33.55 & 52.00 & 18.95 & ---- & 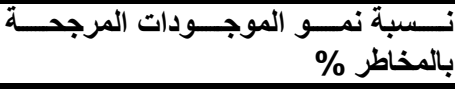 \\
\hline 15.3 & 15.9 & 19.1 & 20 & نسبة كفاية رأس الماله\% \\
\hline
\end{tabular}

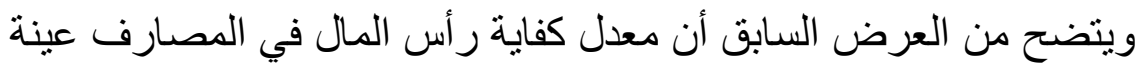

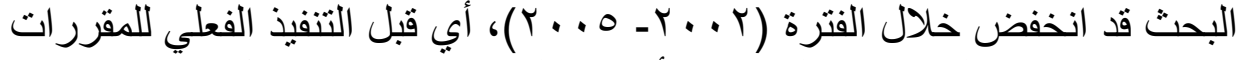

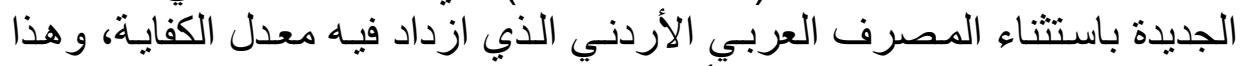

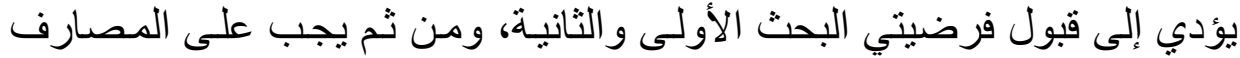

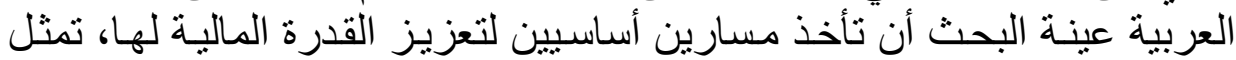

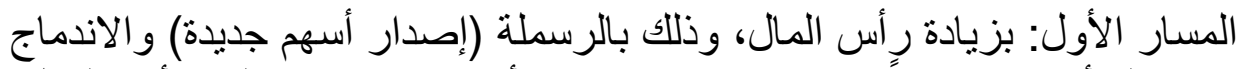

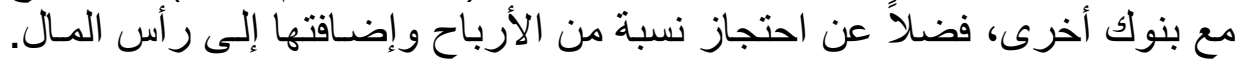

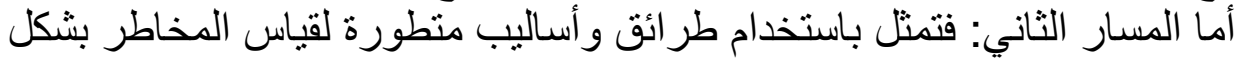

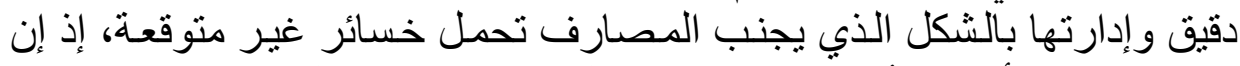

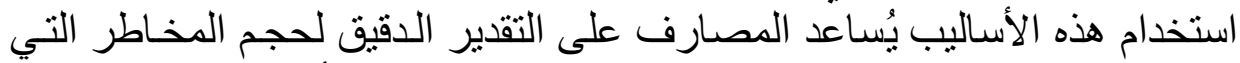

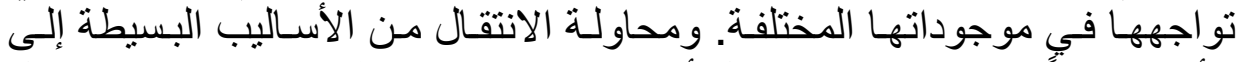

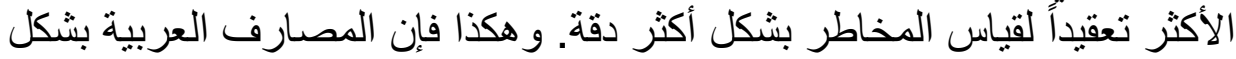

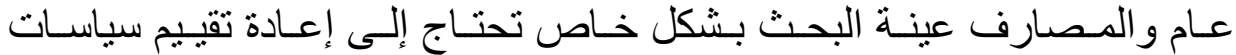

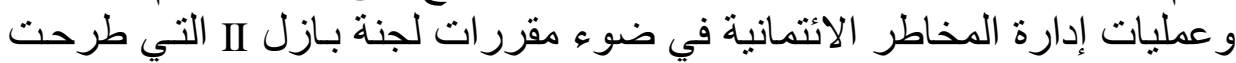

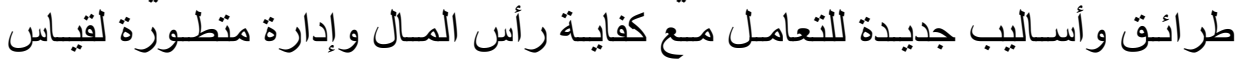

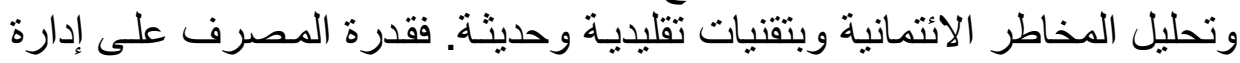

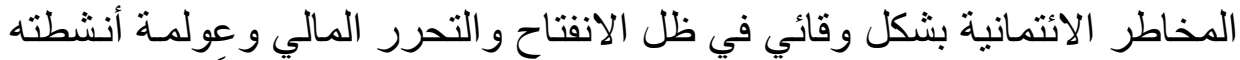

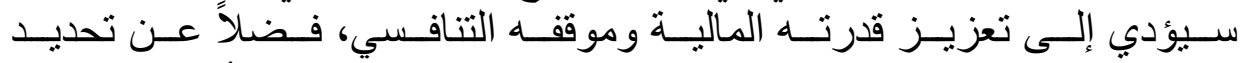

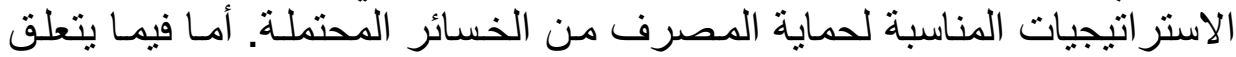

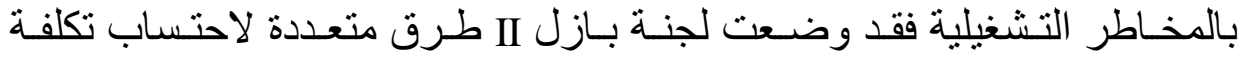

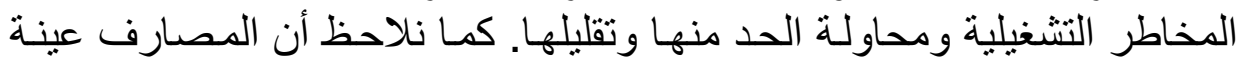

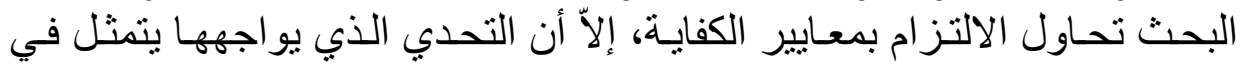

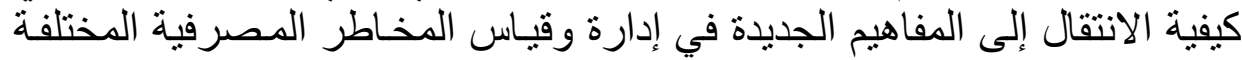

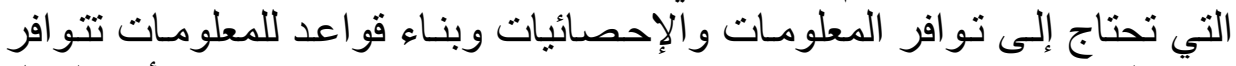

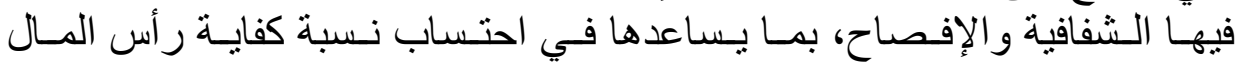


و المساهمة في تطوير منهجيـة لاتخاذ قرارات الإقر اض وتحديد ربحية الزبائن و العمليات حسب درجة المخاطرة.

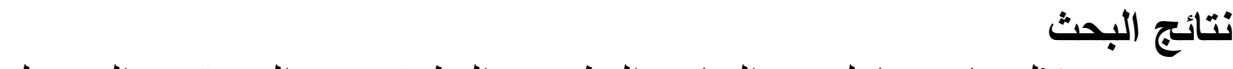
من خلال ما تم تناوله في الجانب النظري و التطبيقي من البحث تم التوصل

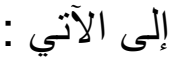

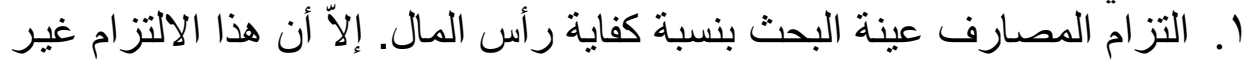

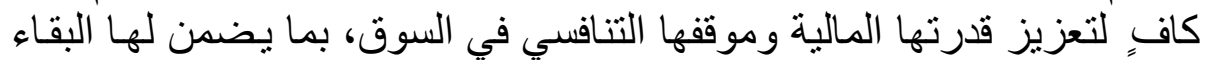

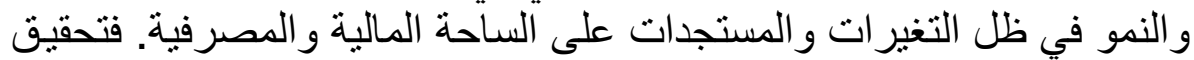

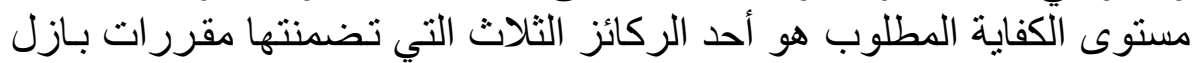

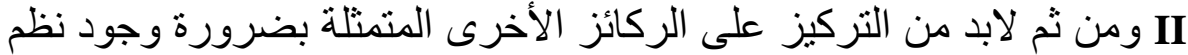

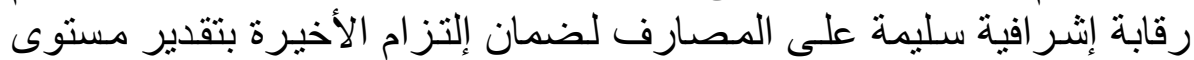

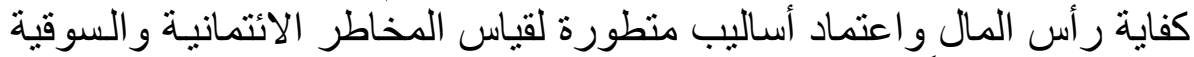

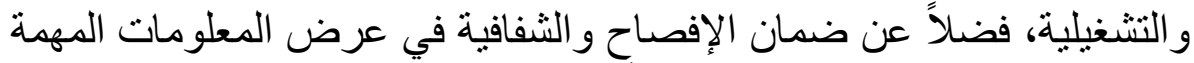

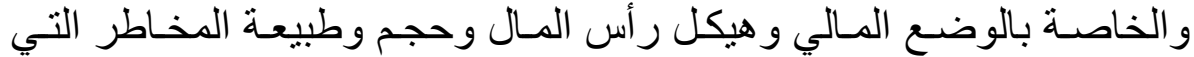

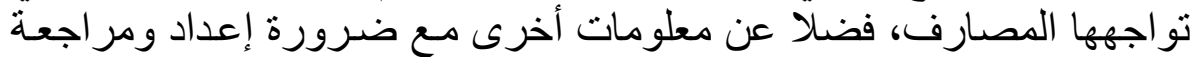

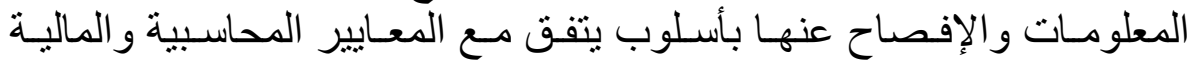

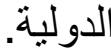

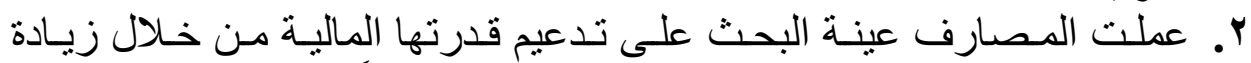

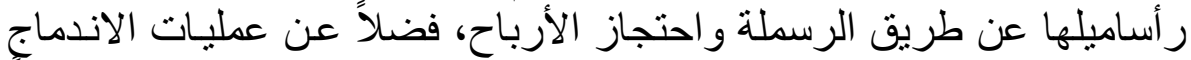

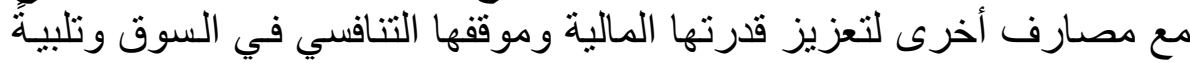

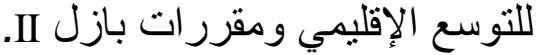

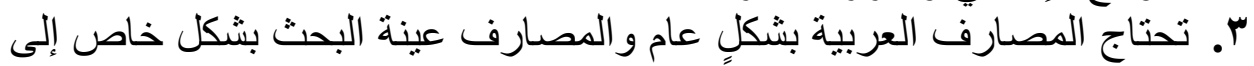

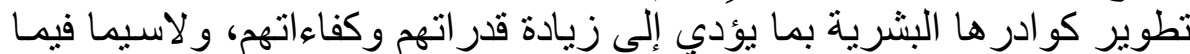

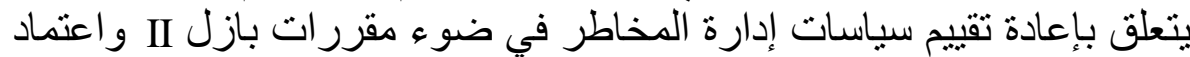

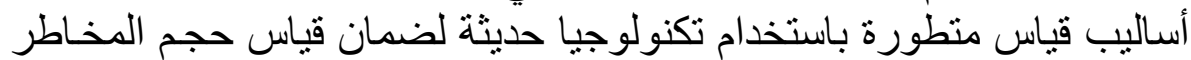

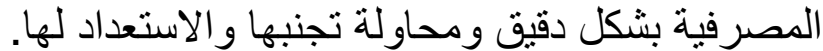

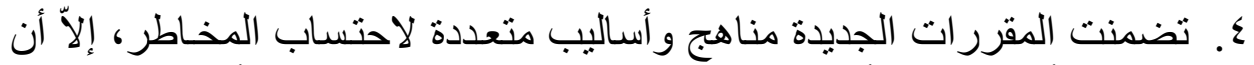

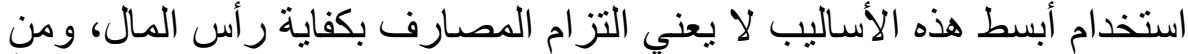

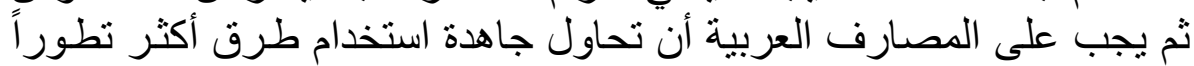

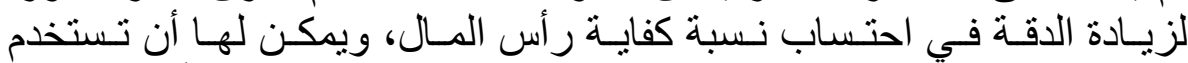

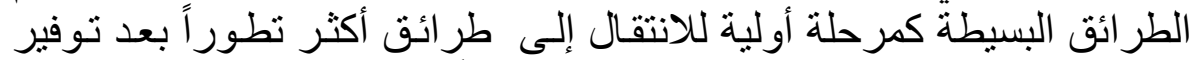

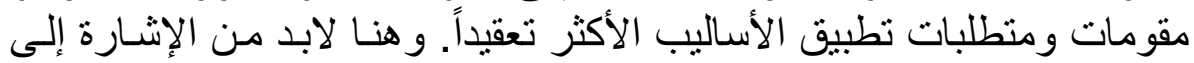

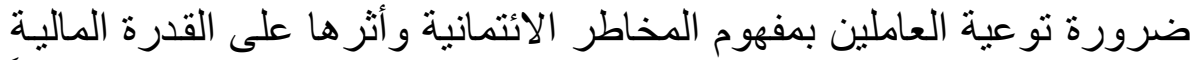

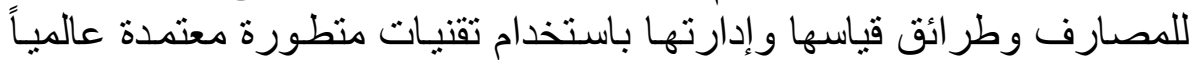
للارتقاء بمستوى العاملين وزيادة كفاءتهم وقدر اتهم تماشياً مـع مقرر بات بـات بـازل 


\section{[rvy] محمد}

•. تصنف الدصارف العربيـة في ظل الدقرر ات الجديدة إلى ثلاثـة مستويات

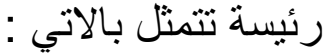

المستوى الأول : يضم المصارف التي تتمتع بملاءة مالية تفوق معدل كفاية رأس

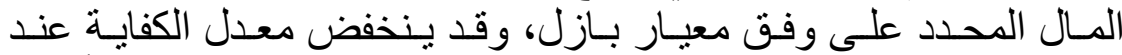

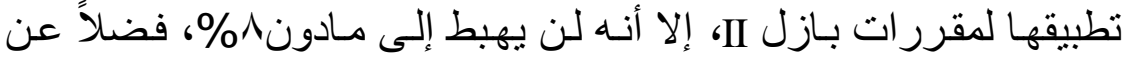

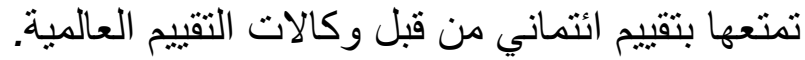

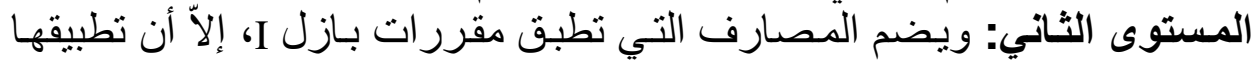

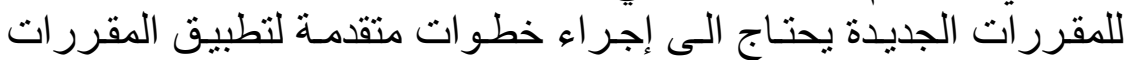

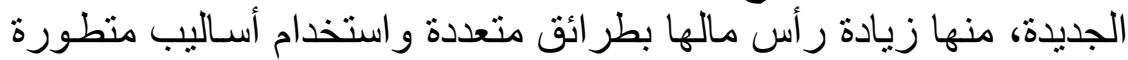

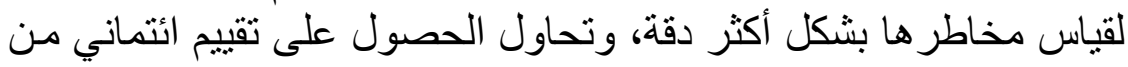
قبل وكالات التقبيم العالمية.

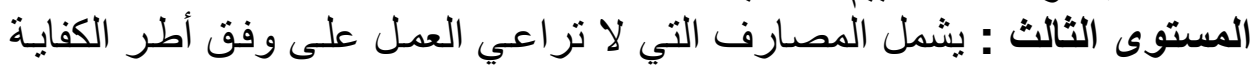

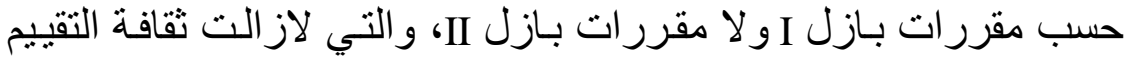

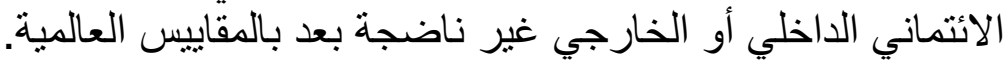

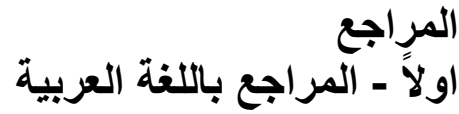

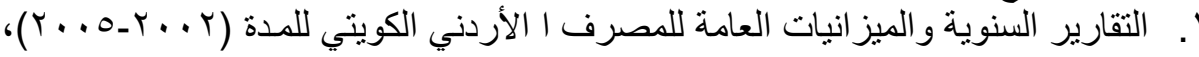

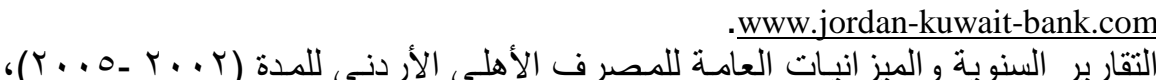
بww.ahli.com

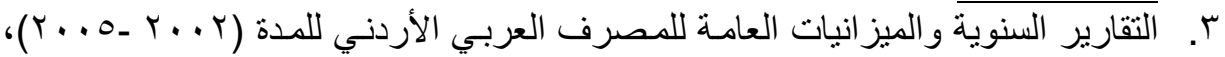

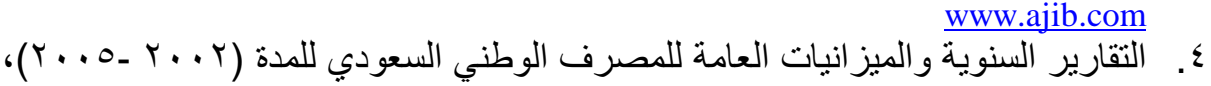
.www.anb.com.sa

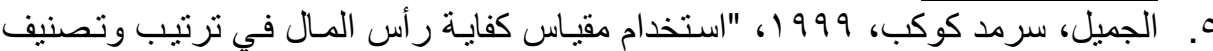

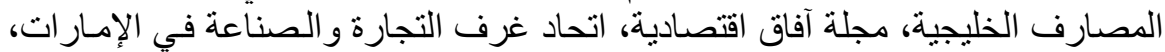

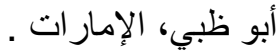

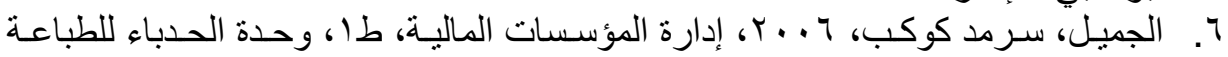

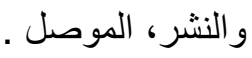

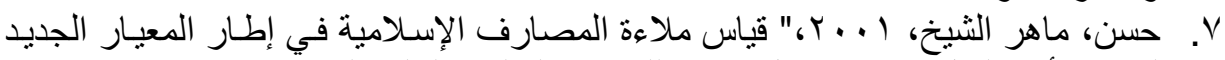

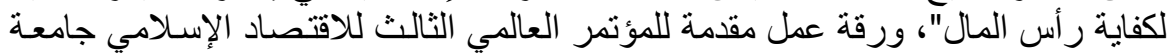

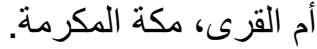

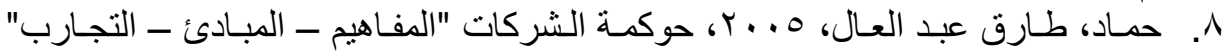

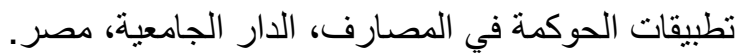

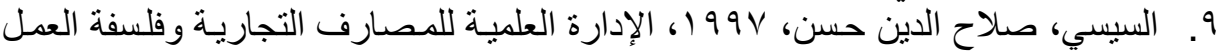

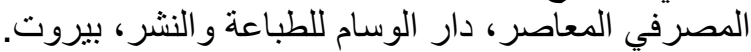

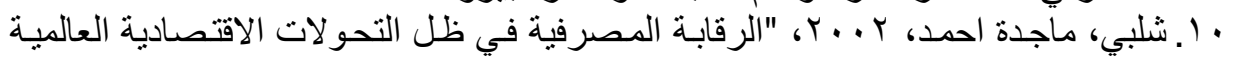

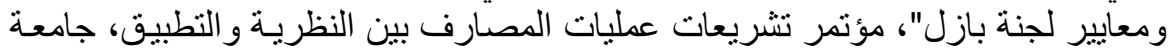

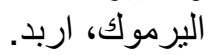




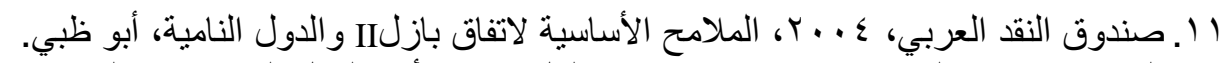

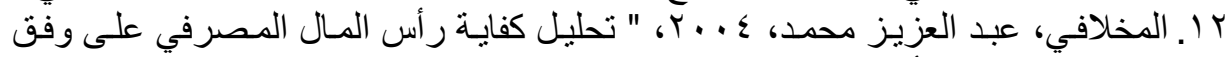

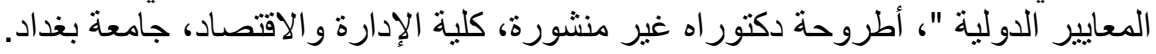

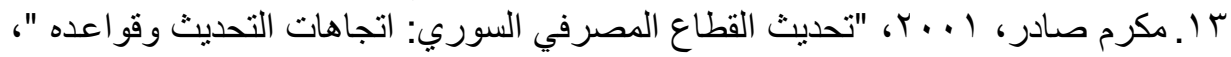

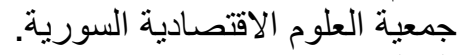

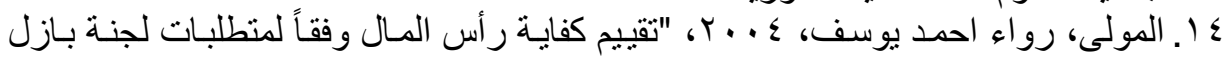

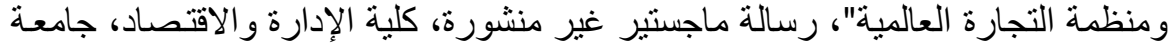

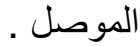

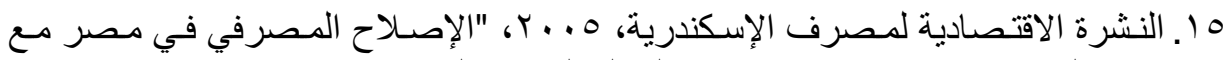

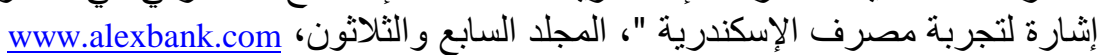

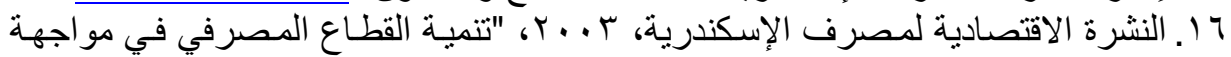
تحديات العولمة"، المجلد الخامس و الثلاثون، www.sham.net. IV

\section{ثانياً. المراجع باللغة الأجنبية}

1. Hennie Van Greuning, 2000, Analyzing Banking Risk, The World Bank, Washington, D.C.

2. Maher Hasan, 2002,"The Significance of Basel I and Basel II for the future of the Banking Industry with special emphasis on credit information ",Central Bank of Jordan. 